\title{
BONODA DÜZENLEME YERİ
}

\section{İsmail Özgün KARAAHMETOĞLU*}

\section{$\ddot{O} Z$}

Bononun şekli şartlarından düzenleme yeri alternatif zorunlu bir unsur olarak kabul edilmektedir. Bu yüzden düzenlendiği yer gösterilmeyen bir bono, düzenleyenin adının yanında yazılı olan yerde düzenlenmiş sayılır. TTK'da konuyla ilgili hükümlerinde bonodaki düzenleme yerinin nasıl ve ne şekilde tespit edileceğine dair herhangi bir bilgi verilmemiştir. Bu çalışmada bonoda düzenleme yerine dair hem Yargıtay kararları hem de doktrindeki görüşler ışığında yapılan tartışmalara değinilerek düzenleme yeri ile ilgili hukuki sorunların ortaya konulması ve bunlara bir çözüm getirilmesi amaçlanmıştır. Bu bağlamda bonoda düzenleme yerinin anlamı, önemi, bu yer açısından özellik arz eden durumlar (mülki idari birim ve kısaltılarak yazılabilme), hükmün ele alındı̆̆ düzenlemenin hukuki yerindeliği ve düzenleme yerinin geçersizliğine bağlanan hüküm ve sonuçlar (soyut borç ikrarl) Alman, Isviçre ve Türk hukuku çerçevesinde ayrıntılarıla incelenmiştir.

Anahtar Kelimeler: Bono, alternatif zorunlu unsur, düzenleme yeri, mülki idari birim, soyut borç ikrarı.

\section{PLACE OF THE ISSUE IN THE BILL}

\section{ABSTRACT}

The place of issue is considered as an alternative mandatory element from the formal elements of the bill. Hence, a bill that does not show its place of issue is deemed to have been issued in the place written next to the issuer's name. No data has been specified in the Turkish Commercial Code (TCC) regarding how and no matter how the place of issue in the bill will be recorded in the relevant provisions. In this study, it is intended to clarify the legal problems related to the place of regulation and to find a resolution to them by referring to the discussions made in the consideration of both the decisions of the Supreme Court and the opinions in the doctrine. Within

* Arş. Gör. Dr., Erciyes Üniversitesi Hukuk Fakültesi Ticaret Hukuku Anabilim Dalı/ KAYSERİ, e-posta: o.z_g.u.n@hotmail.com

ORCID : 0000-0002-9660-4575

DOI : :10.34246/ahbvuhfd.933983

Yayın Kuruluna Ulaştığı Tarih : 17/01/2021

Yayınlanmasının Uygun Görüldüğü Tarih: 26/04/2021 
this context, the content and significance of the place of issuance in the bond, the special situations in terms of this place (the çivil administrative unit and reductively writing), the legal appropriateness of the regulation in which the provision is ensured, and the provisions and consequences linked to the invalidity of the place of issue (abstract acknowledgment of debt) has been examined thoroughly within the scope of German, Swiss and Turkish law.

Keywords: Bill, alternative mandatory element, place of issue, the civil administrative unit, abstract acknowledgment of debt.

\section{GENEL OLARAK}

Bono (6102 sayılı TTK m. 776), diğer bir adıyla emre yazılı senet (6762 say1lı TTK m. 688 ile 865 sayıl1 Kanun’un 604. maddesi) bir kambiyo senedidir. İsviçre ve Alman hukukunda ise bonoyu ifade etmek için sırasıyla OR Art. 1096' da ve WG Art. 75'te 'eigener Wechsel' ibaresi tercih edilmiştir. Bono, bir ödeme aracı ya da teminat amaçlı olarak kullanılmasının yanı sıra kredi işlevine de sahiptir ${ }^{1}$. Kimi zaman da bono kısa vadeli yatırım aracı olarak da kullanılmaktadır².

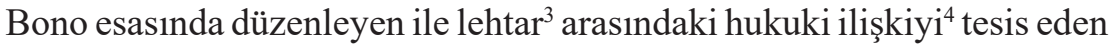
bir ödeme vaadi niteliğindedir ${ }^{5}$. Bu yüzden, bonoyu düzenleyen asli borçlu

1 Firat Öztan, Kıymetli Evrak Hukuku, Güncelleştirilmiş 21. Bası, Turhan Kitabevi, 2017, s. 207; Reha Poroy/Ünal Tekinalp, Kıymetli Evrak Hukuku Esasları (Çek Kanunun Yorumu İle), Gözden Geçirilmiş 21. Bası, Vedat Kitapç1lık, 2013, N. 410, s. 281; Abuzer Kendigelen/İsmail Kırca, Kıymetli Evrak Hukuku (Genel Esaslar-Kambiyo Senetleri), Güncellenmiş 3. Bası, Onikilevha Yayıncılık, 2020, s.160; Mehmet Bahtiyar, Kıymetli Evrak Hukuku (Ders Notlar1- Soru Örnekleri), Güncellenmiş 18. Bas1, Beta Yayınevi, 2020, s. 121-122; Ali Bozer/Celal Göle, Kıymetli Evrak Hukuku, Güncellenmiş ve Genişletilmiş Sekizinci Bası, Banka ve Ticaret Hukuku Araştırma Enstitüsü Yayınları, 2018, s. 183 ve 184; İsmail Kayar, Kiymetli Evrak Hukuku, Altınc1 Bas1, Detay Yayınc1lık, 2013, s. 122.

2 Öztan, s. 208; Bahtiyar, Kıymetli Evrak, s. 122; Kayar, s. 123.

3 Lehtar tüzel kişi de olabileceğinden TTK m. 777/1/e'deki ifadenin 'kime veya kimin emrine ödenecek ise onun adl-soyadını ya da unvanını" şeklinde yazılması gerektiği yönündeki görüş için bkz. Mehmet Bahtiyar, "Türk Ticaret Kanunu Tasarısı'nın Dili İle Bazı Hükümlerinin Değerlendirilmesi”, 2005, 18(61), TBB, s. 99, http://tbbdergisi.barobirlik.org.tr/m200561-183 Erişim Tarihi 25.11.2020.

4 Pekâlâ bono ciro edildiğinde veyahut bonodan ötürü sorumlu kişiler lehine aval verildiğinde bu sayı artacaktır. Bkz. Bahtiyar, Kıymetli Evrak, s. 121.

5 Gönen Eriş, Türk Ticaret Kanunu Hükümlerine Göre Kıymetli Evrak, 1. Baskı, Seçkin Ya- 
sıfatına sahiptir ${ }^{6}$. Şu hâlde bir bonoyu düzenleyen ${ }^{7}$ kişi, tıpkı bir poliçeyi kabul eden gibi sorumludur (TTK m. 779/1). Nitekim bonoyu düzenleyen ile ödeme yapacak kişi aynı olduğundan, muhatabın varlığından bahsedilemez $z^{8}$.

\section{BONONUN ŞEKLİ ŞARTLARINDAN DÜZENLEME YERI'}

Bir senedin bono sayılabilmesi için TTK m. 776' da sayılan unsurların TTK m. 777/1 hükmü uyarınca bu senet içerisinde bulunması gerekir. Bu bağlamda bonodaki şekli unsurlar mutlak zorunlu kayıtlar, alternatif zorunlu kayıtlar ile ihtiyari kayıtlar olmak üzere üçe ayrılır ${ }^{10}$. Şu hâlde senede açıkça yazılmamış olsalar bile eksiklikleri başka bir yoldan giderilmiş sayılan kayıtlardan biri olan bonoda düzenleme yeri alternatif zorunlu kayıtlar içerisinde değerlendirilir ${ }^{11}$. Diğer bir deyişle, her ne kadar düzenleme yerinin bonoda yer alması zorunlu

yıncılık, 2014, s. 538; Kendigelen/Kırca, s. 161; Bozer/Göle, s. 182.

6 Bahtiyar, Kiymetli Evrak, s. 121; Bozer/Göle, s. 181.

7 Düzenleyen ibaresinin kambiyo senetlerinden yalnızca bono için kullanılması gerektiği yönündeki görüş için bkz. Bahtiyar, TBB, s. 87.

8 Arthur Meier Hayoz/ Hans von der Crone, Wertpapierrecht, Zweite, überarbeitete Auflage,Stämpfli Verlag AG Bern, 2000, § 14, Rn.4, s. 205; Werner Schoele, Der Wechsel, Heft 78, R. Booberg Verlag, 1956, s. 7; Öztan, s. 207 ve 208; Kendigelen/Kırca, s. 162; Bahtiyar, Kıymetli Evrak, s. 121; Bozer/Göle, s.181; Kayar, s. 121-122.

9 Bonoda 'düzenleme yeri' ibaresi yerine sirasiyla TTK m. 672/4, 707/1, 781/3, 796/2, 821/I'de de görüleceği üzere 'düzenlenme yeri' ibaresi kavramı kullanılmıştır. Ancak biz 'düzenleme yeri' ibaresinin kullanılmasının daha yerinde olacağı kanaatiyle söz konusu makalenin yazımında kavramı bu şekilde kullanacağız.

10 Yaşar Karayalçın, Ticaret Hukuku Dersleri (II. Ticari Senetler -Kambiyo Senetleri-, Üçüncü Bask1, Güzel İstanbul Matbaası, 1964, s. 78; Hayri Domaniç, Kıymetli Evrak Hukuku ve Uygulamas1, TTK Şerhi-IV, 1. Bası, Eskin Matbaası, 1990, s. 478; Talih Uyar, "İcra Hukukunda Bono'nun (Emre Muharrer Senet'in) Geçerlilik Koşulları”, 2008, 20(74), TBB, s. 291, <http://tbbdergisi.barobirlik.org.tr/m2008-74-395> Erişim Tarihi 25.11.2020; Talih Uyar/Alper Uyar/ Cüneyt Uyar, İcra Hukukunda Kambiyo Senetleri (İIK. 167-170b), 4. Bask1, Bilge Yayınevi, 2013, s.5; Poroy/Tekinalp, N. 215 vd., s. 158 vd.; Hasan Pulaşlı, Kıymetli Evrak Hukukunun Esasları, Genişletilmiş ve Güncellenmiş 5. Bask1, Adalet Yay1nevi, 2017, s. 131; Basler Kommentar Wertpapierrecht, Marc Grüninger/ Bruno Hunziker/ Gerhard Roth, Helbing Lichtenhahn Verlag, 2012, Art 991 OR, Rn. 24; Oğuz İmregün, Kiymetli Evrak Hukuku (Genel Hükümler-Kambiyo Senetleri-Makbuz Senedi-Varant), 1. Bas1, Filiz Kitabevi, 1995, s. 52; Kendigelen/Kırca, s. 164; Bahtiyar, Kıymetli Evrak, s. 126-127; Bozer/Göle, s. 185; Kayar, s. 124.

11 Fahiman Tekil, Kıymetli Evrak Hukuku, Beta Yayınevi, 1980, s. 117; Naci Kınacıŏlu, Kıymetli Evrak Hukuku, 5. Bask1, Nobel Yayınevi,1999, s. 113, İmregün, s. 52; Domaniç, s. 473; Bozer/Göle, s. 209; Pulaşl1, s. 140; Eriş, s. 540; Bernhard Rehfeldt/Wolfgang Zöllner, Wertpapierrecht, 10. Auflage, Verlag C H Beck München, 1972, s. 58; Peter Bülow, Wechselgesetz/Scheckgesetz, 5. neu bearbeitete Auflage, Verlag C. F. Müller, 2013, WG Art. 75, Rn.10, s. 348; BSK Wertpapierrecht- Grüninger/Hunziker/Roth, Art 991 OR, Rn. 22. 
ise ${ }^{12}$ de ilk aşamada bu eksiklik bononun geçersizliğine sebebiyet vermemekte ve alternatif olarak bonodaki diğer unsurlar bunun yerine ikame edilmektedir. Bu sayede bono geçerliliğini devam ettirebilmektedir. Nitekim TTK m. 777/4 hükmü uyarınca düzenlendiği yer gösterilmeyen bir bono, düzenleyenin adının yanında yazılı olan yerde düzenlenmiş sayılır. Aksi takdirde düzenleme yerinin gösterilmediği ve düzenleyenin adının yanında da herhangi bir yer belirtilmediği durumda bono geçersiz olacaktır ${ }^{13}$.

\section{DÜZENLEME YERININ ÖNEMI}

Bonoda düzenleme yeri devletler özel hukuku açısından TTK m. 778/1j bendi uyarınca ayrı bir önemi haizdir. Şöyle ki; bononun niteliğine aykırı düşmedikçe kanunlar ihtilafına dair poliçe bakımından öngörülen TTK m. 776 ila 775 hükümleri bonoya tatbik edilebilir. Konuya bonoda ödeme yerinin ${ }^{14}$ kararlaştırıldığı varsayımdan hareketle yaklaşıldığında, TTK m. 766/1 hükmü uyarınca; bir kişinin bono ile borçlanması için gereken ehliyet tabi bulunduğu devletin hukukuna göre tayin edilir. Burada senedi düzenlendiği yer ile ödeneceği yerin farklı mahal olabileceğini görmek suretiyle kastedilenin senedin düzenlendiği, yani imzalandığı yer olduğunu kabul etmek gerekir ${ }^{15}$. Benzer şekilde, bono ile yapılacak borçlanmaların şekli (TTK m. 767/1), bono borçlularının başvurma haklarını kullanması için uymaları gereken süreler (TTK m. 769/1), bonodaki diğer borçluların hukuki durumu (TTK m. 770/2) da bononun düzenlendiği yer hukukuna göre tespit edilir. Bununla birlikte bonoda ödeme yerinin kararlaştırılmadığı varsayımda ise artık bonodaki asli ya da alternatif mahiyetteki düzenleme yeri ödeme yerine bağlanan sonuçları kendisine tabi tutmuş olacaktır. Bu cihetle borçlanma (TTK m. 770/1), kısmi ödeme (TTK m. 771/1), genel olarak ödeme (TTK m. 772/1) ve son olarak da

12 Mehmet Özdamar/Kürşat Göktürk/Mehmet Çelebi Can/Esra Kaşak, Kıymetli Evrak Hukuku, Birinci Bası, Adalet Yayınevi, 2020, s. 205.

13 Bülow, WG Art. 75, Rn. 10, s. 348.

14 Bonoda ödeme yerinin senedin geçerliliği bakımından ihtiyari bir unsur olarak ele alınması gerekliliği hasıl olmuştur. Zira bonoda düzenleme yerinin bir şekilde bulunması halinde artık ödeme yerinin ayrıca belirtilmesine gerek yoktur. Zaten bonoda açıklık bulunmadığ takdirde senedin düzenlendiği yer ödeme yerinin yerine geçecektir (TTK m. 777/3). O halde denilebilir ki; bonodan doğan taahhüdün düzenleme yerinden başka bir yerde ödenmesi isteniyorsa ödeme yerine ilişkin kaydın ayrıca belirtilebilir. Bununla birlikte uygulamada bonoda düzenleme ile ödeme yerini gösterilmeyerek düzenleyenin adının yanında gösterilen yerden hareketle ödeme yerinin tespit edildiği görülmektedir. Bkz. Kendigelen/Kırca, s. 170 .

15865 sayılı Kanun döneminde benzer yönde bkz. Arslanlı, s. 63. 
bononun kaybolması veya çalınması hallerinden birinde alınacak tedbir -iptal karar1- (TTK m. 775/1) ödeme yerindeki, yani düzenleme yeri hukukuna göre belirlenir. Pek tabidir ki, bu hukuki sonuçlar yabancıllk unsurunu ihtiva eden bir bonoya ilişkin bağlama kuralı olarak uygulanacak hukuku tespit etmektedir. İç hukuk bağlamında ise sürelerin hesabından takvimlerin çatışması (TTK m. 778/1 b bendi yollamasıyla TTK m. 707), yabancı ülke parası ile ödeme (TTK m. 778/1-c bendi yollamasiyla TTK m. 711) hallerinde ödeme yeri açıkça kararlaştırılmadıysa artık var olan düzenleme yeri esas alınarak işlem yapılacaktır. Bunların haricinde adresli veya yerleşim yerli bonolarda ${ }^{16} \mathrm{da}$ ödeme yerinin açıkça yazılmadığ 1 durumlarda düzenleme yerinden istifade edilecektir.

Bonodan kaynaklı uyuşmazlıklarda bilhassa bonoya dayalı kambiyo senetlerine mahsus haciz yolu ile takip yapılmak istendiği takdirde yetkili icra dairesinin tespitinde ${ }^{17}$ bonodaki düzenleme yeri yol gösterici niteliktedir ${ }^{18}$; yoksa belirleyici değil! Mevzuata genel olarak bakıldığında, İiK m. 50/12. cümlesi uyarınca takibe esas olan akdin yapıldığı icra dairesi de takibe yetkilidir. Ayrıca İIKK m. 50/1-1. cümlesinin yollamasıyla HMK m. 10 hükmü bağlamında sözleşmeden doğan davalar, sözleşmenin ifa edileceği yer mahkemesinde de açılabilir. Oysaki bu hükümler ilk bakışta kambiyo senetleri bakımından bir anlam ifade etmemektedir. Çünkü bono nitelikli bir soyut borç ikrarı olup ${ }^{19}$ taahhüdün yerine getirilmesi açısından TBK m. 89/1-3. bent

16 TTK m. 778/2-a bendi yollamasıyla TTK m.674 ve 697 hükümleri. TTK m. 739 hükmü bonoda muhatap bulunmadığından bahisle kabul noktasında uygulanmayacaksa da, araya girme suretiyle ödeme açısından TTK m.778/1-e bendinin açıkça TTK m.734,738 ila 742 hükümlerine yollama yapması hasebiyle uygulanacaktır. Bu yönde bkz. Kendigelen/Kırca, s. 155 .

17 Bonoya yetki şartı konulması hakkında ayrıntılı açıklamalar için bkz. Levent Börü, "Bonoya Dayal1 Kambiyo Senetlerine Özgü Haciz Yolu İle Takipte Yetki”, AÜHFD, 2016, 65(1), s. 152 vd., <https://dergipark.org.tr/tr/download/article-file/622108> Erişim Tarihi 25.101.2020. Bu konuda yol gösterici nitelikteki karar için bkz. YHGK, 19.03.2019, E. 2017/721, K. 2019/324, <https://karararama.yargitay.gov.tr/ >Erişim Tarihi 20 Aralık 2020.

18 YHGK, 19.03.2019, E. 2017/721, K. 2019/324; Y.12.HD., 18.04.2017, E. 2016/13884, K. 2017/5971, <https://karararama.yargitay.gov.tr/ >Erişim Tarihi 20 Aralık 2020.

19 Özlem Karlı, Sebebi Gösterilmeyen Borç Tanıması (Mücerret Borç İkrarı) BK. Mad. 17, 1. Bas1, Vedat Kitapçılık, 2008, s. 11; Hüseyin Ülgen/Mehmet Helvac1/Arslan Kaya/Füsun Nomer Ertan, Kıymetli Evrak Hukuku, Güncellenmiş ve Kısmen Yeniden Yazılmış 11. Bası, Vedat Kitapçılık, 2019, s. 137; Öztan, s. 206; Kendigelen/Kırca, s. 161; Bahtiyar, Kıymetli Evrak, s. 121; Bozer/Göle, s. 182; Kayar, s. 123 ve 124; Özdamar/Göktürk/Can/Kaşak, s. 196. 
uyarınca aranılacak borcun ${ }^{20}$ doğumu sırasında düzenleyenin yerleşim yerinin esas alınması gerekir. Nitekim TTK m. 778/1-i bendinin yollamasıyla TTK m. 755/1 hükmü uyarınca, ödeme için ibraz varsa bonoyu düzenleyenin ticaret yerinde, bu da yoksa konutunda gerçekleştirileceğinden HMK ve İIK'nın ilgili hükümlerinin bu kapsam içerisinde değerlendirilmesi icap eder ${ }^{21}$. Diğer bir deyişle, düzenleme yeri her zaman düzenleyenin yerleşim yeri/ticaret yeri olamayacağından ve TTK m. 776/1-d bendi uyarınca, özel yetkili icra dairesi olarak da ödeme yerinde ${ }^{22}$ icra takibinde bulunabileceğinden tabir-i caizse düzenleme yerinin varlığına doğrudan bel bağlanmamalıdır. Bununla birlikte düzenleme yerinin ödeme yerinin yokluğu halinde hayat bulduğu olasılıklar dahilinde bonoya dayalı icra takibi düzenleme yerindeki icra dairesinde yapılabilecektir. Ayrıca adresli ya da yerleşim yerli bonolar açısından $\mathrm{da}^{23}$ bono düzenleyenin yerleşim yerinde düzenlendiğinde düzenleme yeri gene bonoya dayalı yapılacak icra takibinde yetkili icra dairesinin tespiti noktasinda belirleyici olacaktır (TTK m.778/2-a bendi yollamasıyla TTK m. 674).

\section{DÜZENLEME YERİ AÇISINDAN ÖZELLİK ARZ EDEN DURUMLAR}

Bonoda düzenleme yerinin senede ne şekilde yansitılacağ 1 konusunda TTK'da herhangi bir hüküm yoktur. Haliyle senet metninde düzenleme yerine okunaklı ve anlaşı1ır olması kaydıyla herhangi bir araç vs. ile yer verilmesi düzenleme yerinin geçerliliğine halel getirmez. Böylelikle düzenleme yerinin

20 "Mahkemece, tüm dosya kapsamina göre, kambiyo senetlerinden doğan alacakların aranacak alacaklardan olduğu, kambiyo senedi alacaklısının kendi ikametgahında takip yapamayacağı, borçlunun ikametgahında takip yapabileceği, takibin girişildiği yerin alacaklının ikametgahı icra müdürlüğ̈̈ olduğu, borçluların ikametgahının ... olduğu, takibin ... icra dairelerinin yetkisinde olduğu, gerçek kişi tarafların düzenledikleri bonodaki yetki şartının geçerli olmadığı, borçluların yerleşim yeri ile bononun tanzim yerinin ... olmadiğı gerekçesiyle ihtiyati haciz kararına yapılan itirazın kabulüne karar verilmiştir." Y. 11. HD., 22.03.2017, E. 2017/902, K. 2017/1731, <https://karararama.yargitay.gov.tr/ > Erişim Tarihi 20 Aralık 2020.

21 Benzer yönde bkz. Börü, s. 146.

22 Börü, s. 146-147.

23 Börü, s. 147-148. Ayrıca bkz. Alfred Hueck, Recht der Wertpapiere, 10. Auflage, Verlag Franz Vahlen GmbH Berlin und Frankfurt a. M., 1967, § 8, s. 39. 
kaşe basılarak gösterilmesi ${ }^{24}$, daktilo ${ }^{25}$, herhangi bir kalem ile el yazıs ${ }^{26}$ ya da başkaca el ürünü olması herhangi bir farkl11ık yaratmaz ${ }^{27}$. Hatta matbu (basıl1) bir bono örneğindeki boşluklar doldurularak da geçerli bir kıymetli evrak ihdas edilebilir ${ }^{28}$.

Düzenleme yerinin dilbilgisi açısından isim ya da sıfat bağı ile belirtilmesi açısından herhangi bir farklılık yoktur ${ }^{29}$.

Düzenleme yerinin bonoda nereye yazılacağı konusunda TTK'da bir açıklık söz konusu değildir ${ }^{30}$. Düzenleme yerinin uygulamada senedin üstüne ya da altına yazıldığ bilinmektedir $^{31}$. Bununla birlikte düzenleme yerinin düzenleyenin adının altına yazılması zorunlu değildir ${ }^{32}$. O halde bonoya bağlı alonj olarak ifade edilen bononun arka yüzünün devamı niteliğindeki kâğıt üzerine de düzenleme yerinin yazılabileceğini ${ }^{33}$ söyleyebiliriz. Pek tabidir ki, bu tür durumlarda önemli olanın TTK m. 776/1 hükmü uyarınca bono ya da emre yazılı senedin düzenleme yerini içeriyor olması gerektiğidir; yoksa

24 Y. 12. HD., 14.11.1985, E. 4015/K. 9603 ve Y. 12. HD., 26.2.1985, E. 120321/1750. Bkz. Uyar, s. 35. Senedin düzenleme yeri açıkça yazılmamıștır. Şirket de borçlu olup, kaşede "Adana" yazılı olduğundan bu senet bono niteliğindedir (Y. 12. HD., 09.10.2000, E. 13809/K. 14600). Bkz. Eriş, s. 619. Çek açısından benzer yönde bkz. Erdoğan Moroğlu, "Kambiyo Senetlerinde Düzenleme Yeri", Makaleler, Onikilevha Yayıncılık, 2010, dipnot 15, s. 510-511; Abuzer Kendigelen, Çek Hukuku, Gözden Geçirilmiş ve Güncelleştirilmiş 5. Bas1, Onikilevha Yayıncılık, 2019, s. 118.

25 Y. 12. HD., 16.3.1982, e. 1362/K. 2000. Bkz. Uyar, s. 35.

26 Çekler açısından benzer yönde bkz. Kendigelen, Çek, s. 117-118.

27 Moroğlu, s. 510-511; Teoman, Hukuki Mütalaalar 149, s. 124-125. Çekler açısından bkz. Kendigelen, Çek, s. 118.

28 Teoman, Hukuki Mütalaalar 149, s. 125.

29 Erst Jacobi, Wechsel-Und Scheckrecht unter Berücksichtigung des ausländischen Rechts, Unveränderter Nachdruck, Walter De Gruyter \& CO., 1956, § 48, s. 355.

30 Teoman, Hukuki Mütalaalar 149, s. 125.

31 Arslanlı, s. 63. Senedi ödeme vaadinin yer aldığı metin kısmının yanında yer alabileceği yönünde bkz. Özdamar/Göktürk/Can/Kaşak, s. 205.

32 Moroğlu, s. 508; Y. 12. HD., 20.04.1999, E.4661/5017. Bkz. Uyar, s. 35; Uyar, TBB, s. 312. Düzenleme yerinin senet belgesinin herhangi bir yerine yazllabileceği yönünde bkz. BSK Wertpapierrecht- Grüninger/Hunziker/Roth, Art 991 OR, Rn. 22.

33 Ödeme yerinde de benzer bir yaklaşımın kabul edildiğini (bkz. Bülow WG Art. 75, Nr.4, s. 347-348, Art. 1, Rn. 26, s.20-21; Adolf Baumbach/ Wolfgang Hefermehl, Wechselgesetz und Scheckgesetz mit Nebengesetzen und einer Einführung in das Wertpapierrecht, 22. neubearbeitete und erweiterte Auflage, Verlag C.H.Beck München, 2000, WG Art.1, Rn. 10, s. 112); ancak senet metni dahilinde birden fazla düzenleme yerinin kararlaştırılması düzenleme yerinin geçersizliğine sebebiyet verir. 
bu dahil olma kıstasının ${ }^{34}$ ne şekilde gerçekleştirildiğinin bir önemi yoktur. Oysaki Yargıtay bir kararında ${ }^{35}$ "...tanzim yerinin bononun ön yüzünde yazll olması gerekip, arka yüzde yazılı olan yerin tanzim yeri olarak kabulü mümkün değildir..." şeklinde hüküm tesis ederek konuyu dar bir bakış açısıyla ele almıştır. Oysaki mezkûr kararda asli ve alternatif unsur olarak herhangi bir idari birimin olmamasından hareketle bu sonuca ulaşılırken, ayrıca düzenleme yerinin yalnızca senedin ön yüzüne hasredilmesi ${ }^{36}$ doğru bir yaklaşım değildir. Zira senedin bono niteliğini kazanması düzenleyenin imzasına bağlı olduğundan ${ }^{37}$ bu imzanın da senetteki düzenleme yerini kapsadığının ispatı halinde artık bonodaki düzenleme yerinin varlığı kabul edilmelidir. Nihayetinde bonodaki düzenleme yerinin senedin arka yüzüne de yazılabileceği ve bunun geçerli olacağı evleviyetle söylenebilir.

Bonoda düzenleme yerine asli ya da alternatif olarak yer verilmemesi halinde artık üçüncü bir seçenek düşünülemeyeceğinden bononun kambiyo senedi vasfinı yitirmesi icap eder. Bu cihetle kefilin adı ve soyadı yanında

34 Alonj, alelade bir kâğıt parçası olmayıp senedi arka yüzünün devamı niteliğindedir. Haliyle senedin parçası olan alonjun senet ile yalnızca fiziki bir bağın olmadığı, alonja bağlı kayıtların geçerliliğinin senet ile hukuki bir bağın da kurulmasına bağlandığı kabul edilmelidir. Bkz. Hüsnü Turanl1, “Türk Hukukunda Alonj”, 2017, 3(1), TFM, s. 123,< https://dergipark. org.tr/tr/pub/tfm/issue/31322/341754 >Erişim Tarihi 20.11.2020. O halde hem senedin ön yüzüne konulacak kayıtların TTK'nda sınırlı sayıda belirtilmesi (m. 695/1, 803/2 ile 805/1) hem de alonja konulabilecek kayıtlara bakıldığında (ciro, kabul, aval ve mücbir sebep durumlarında ihbar şerhleri vb.) düzenleme yerinin de senedin bir parçası olması hasebiyle hem senedin arkası hem de devamı niteliğindeki alonja yazılabileceği evleviyetle söylenebilir. Benzer yöndeki yaklaşım için bkz. Bülow, WG Art. 1, Rn.39, s. 24.

35 Y. 12. HD., 15.11.2012, E. 2012/22140, K. 2012/33262. Bkz. Uyar, s. 36. Yargitay'1n bir başka kararında ise; "Takibe dayanak bononun incelenmesinde; keşidecisinin muteriz borçlu olduğu, borçlunun kaşesi üzerinde şirketin bağlı olduğu vergi dairesi olarak “... belirtilmiş ise de, senedin ön yüzündeki kaşenin hemen altında borçlunun adresi olan "... ..." adresinin yazll olduğu görülmektedir. Bu durumda, senedin düzenleme yeri, borçlunun ticaret sicilinde de kayıtlı olan adresinin yazılı olduğu "İstanbul" ili olup, senedin kambiyo vasfin taşımadığından söz edilemez.” Bkz. Y. 12. HD, 30.03.2017, E. 2016/25188, K. 2017/4937, $<$ https://karararama.yargitay.gov.tr/ > Erişim Tarihi 20 Aralık 2020. Çekler açısından bkz. Kendigelen, Çek, s. 118. Oysaki düzenleme yerine dair hükümde alternatif unsurda imzadan bahsedilmediği gibi, şirketin kaşesinin düzenleyenin adı yerine kullanılıp kullanılmadığ araştırılmadan -tek başına ticaret sicilindeki kayıtlı adres yeterli bir delil değildir- hemen düzenleme yerinin geçerli olduğu kabul edilmemelidir.

36 Bu yöndeki görüş için bkz. Kınacıoğlu, s. 113; Moroğlu, s. 507; Uyar, s. 36.

37 Baumbach/Hefermehl, WG Art.1, Rn. 12, s. 115. Benzer yönde bkz. Jacobi, § 48, s. 354; Gustav Stanzl, Wechsel-, Scheck- und sonstiges Wertpapierrecht, I. Band, Hermann Böhlaus Nachf./Graz-Köln, 1957, s. 32. 
yazılı olan yer $^{38}$ veyahut avalist/lerin adresleri ${ }^{39}$ senedin düzenleme yerine ikame edilemeyeceği gibi kefil ya da avalist düzenleyen olmadığından bu ibarelere itibar edilemez. Benzer durum, lehtarın adının yanında gösterilen yer, ortaya çıkabilecek uyuşmazlıklar bakımından konulan yetki kayd ${ }^{40}$ için de geçerlilik arz eder ${ }^{41}$. Hatta düzenleme tarihinin yanında veyahut altında yazılı olan yerin de düzenleme yeri olarak -kural olarak- kabul edilmemesi gerekir $^{42}$. Haliyle bu tür durumlarda bononun geçersizliği gündeme gelir. Oysaki düzenleme yerinin düzenleyenin ticaret unvanında gösterilen yer olabileceğ ${ }^{43}$, bu olasılık dahilinde her bir somut olayın kendine özgü şartları içerisinde bir değerlendirme yapmak gerektiğini söylemek icap eder. Her ne kadar Yargitay bir kararında ${ }^{44}$ haklı olarak; “... somut olayda takip dayanağl bonoyu düzenleyenin ...olduğu, senette düzenleme yeri yazılı olmadı $\breve{g} l$ olmadığı gibi, senedi düzenleyenin adı ve soyadl yanında da yazllı bir idari birimin bulunmadı̆ğ görülmektedir. Borçlunun ünvanında, ...adının geçmesi anılan maddede kastedilen düzenleyenin adl yanında yazılı yer olarak yorumlanamaz..." şeklinde aksi yönde bir hüküm tesis etmiş olsa da ${ }^{45}$ örneğin; borçlunun mükerrer defa ticaret unvanına dair kaşeyi kullanması durumunda kaşedeki adresin belirli şartlar dahilinde düzenleme yeri olarak kabulünü gerektirir. Oysaki Teoman'ın da kaleme aldığı bir hukuki mütalaasında haklı olarak belirttiği üzere ${ }^{46}$; bono açısından antetli kâğıt üzerinde yer verilen birden çok adresin hangisinin düzenleme hangisinin ödeme yeri olacağı düzenleyenin

38 Y. 12. HD., 05.04.2007, E. 4127/6600. Bkz. Uyar, s. 34.

39 Y. 12. HD., 03.03.2008, E.1185/K. 3982. Bkz. Uyar, s. 34; Ülgen/Helvac1/Kaya/Nomer Ertan, 146; Eriş, s. 550. Çekler açısından bkz. Kendigelen, Çek, s. 116. Y.12.HD., 02.07.2018, E.2017/5880, K. 2018/7116; Y.12.HD., 20.03.2018, E.2016/29762, K. 2018/2821; Y.12. HD., E. 2016/7301, K. 2016/25641, <https://karararama.yargitay.gov.tr/ >Erişim Tarihi 20 Aralik 2020.

40 Y. 12. HD., 09.05.2016, E. 33937/K. 560, <https://karararama.yargitay.gov.tr/ > Erişim Tarihi 20 Aralık 2020. Bozer/Göle, s. 210; Uyar, s. 35.

${ }_{41}$ Kendigelen/Kırca, s. 177; Bozer/Göle, s. 210; Uyar, s. 34. Çekler açısından bkz. Kendigelen, Çek, s. 116-117. Y. 12. HD., 30.03.2017, 20.03.2018, E. 29762/2821, <https://karararama. yargitay.gov.tr/ > Erişim Tarihi 20 Aralık 2020.

42 Aksi yöndeki Y. 11.HD.'inin 17.09.2009 tarih ve 8988/9498 sayılı kararı için bkz. Ülgen/ Helvac1/Kaya/Nomer Ertan, s.146.

43 Stanzl, s. 31.

44 Y. 12. HD, 14.01.2015, E. 2014/26690, K. 2015/560, <https://karararama.yargitay.gov.tr/ >Erişim Tarihi 20 Aralık 2020.

45 Benzer yöndeki görüş için bkz. Kendigelen, Çek, s. 116; Kendigelen/Kırca, s. 177.

46 Ömer Teoman, BONO, Yaşayan Ticaret Hukuku (Hukuki Mütalaalar) KİTAP: 12 20042007, 2008, s. 126. 
kendi iradesi doğrultusunda senet metnine bunu yansitıp yansıtmadığına bağlıdır ${ }^{47}$. O halde söz konusu mütalaada, biri merkez biri de tersane olmak üzere iki ayrı adrese yer verilirken hiçbir tereddüde mahal vermeyecek şekilde düzenleyenin hür iradesinin bir ürünü olmadığı gerekçesiyle bu belgenin bono olarak nitelendirilmesi söz konusu değildir ${ }^{48}$.

Bonoda düzenleme yerinin hangi dilde yazılması gerektiği konusunda TTK'da herhangi bir hüküm yoktur. Yargıtay bir kararında ${ }^{49}$; “...mahkemece, takibe konu bononun düzenlenme yerinin gösterilmediği, yabancı kelimelerle yazılan adresin hangi ülke sinırları içinde olduğu anlaşılamadiğından senedin kambiyo vasfi taşımadĭ̆ gerekçesi ile davanın kabulü ile takibin iptaline karar verilmiştir... Mahkemece; dayanak senedin tanzim yerinin tercüme ettirilerek idari birimi ihtiva edip etmediği tespit edilip, hangi ülke sinırlarl içinde kaldı ̆̆ belirlendikten sonra, tanzim edildiği ülke hukukunu inceleyebilecek yeterlilikte bilen ve özellikle üniversiteden Ticaret ve Kambiyo hukuku dalında bir hukukçu bilirkişiye inceleme yaptırllarak, öncelikle uyuşmazlığa hangi ülke hukuk kurallarının uygulanacă̆ belirlenip, anılan hukuk kurallarına göre takibe konu senedin bono niteliğinde olup olmadiğ (kambiyo senedi vasfinı taşıyıp taşımadiğı) tespit ettirilerek oluşacak sonuca göre karar verilmesi gerekirken, eksik inceleme ile yazılı şekilde hüküm tesisi isabetsizdir." şeklinde tesis ettiği hüküm ile zımnen düzenleme yerinin yazılabileceği dil konusunda Türkçe'nin zorunlu olmadığını kabul etmiş gözükmektedir. Nitekim düzenleme yeri merkez veyahut şube harici bir yer olabileceği gibi, farklı bir ülkede hatta bir kıtada olabileceğinden bahisle ${ }^{50}$ -devletler özel hukuku açısından önemli sonuçlar doğurması yönündendüzenleme yerinin açık ve anlaşılır olması kaydıyla yabancı dilde yazılması -kural olarak- kabul edilebilir.

Bu noktada istisnai hallere özgü olarak 805 sayılı İktisadi Müesseselerde Mecburi Türkçe Kullanılması Hakkında Kanun'un ${ }^{51}$ bonoda düzenleme yeri açısından uygulama alanı bulup bulmayacağını ayrıca irdelemek gerekir. Zira

\footnotetext{
$47 \mathrm{O}$ halde bono sayılan senedin haricindeki bir belgeyle hukuki rabita tesis edildiği hallerde senet metni haricinde düzenleme yerinin kararlaştırılabileceğinin kabulü gerekir kanısınday1z.

48 Teoman, Hukuki Mütalaalar 149, s. 126-127.

49 Y. 12. HD., 28.02.2017, E. 2016/11711, K. 2017/2905, <https://karararama.yargitay.gov.tr/ >Erişim Tarihi 20 Aralık 2020.

50 Teoman, Hukuki Mütalaalar 149, s. 126.

51 RG, 22.04.1926, S: 353, T: 3, C: 7, s. 9.
}

174 Ankara Hacı Bayram Veli Üniversitesi Hukuk Fakültesi Dergisi C. XXV, Y. 2021, Sa. 2 
burada TTK m. 777/1-a bendindeki gibi senet kelimesinin Türkçe yazılmas1 zorunluluğuna dair bir istisna ${ }^{52}$ açıkça öngörülmemiştir. Bu bağlamda 805 sayılı Kanun'un $1 .{ }^{53}$ ve $2 .{ }^{54}$ maddeleri birlikte değerlendirildiğinde Türk tabiiyetindeki ticaret şirketleri ile bir işletmeyi işleten kişilerin (gerçek kişi, tüzel kişi, tüzel kişi olmayan topluluk vb.) bu işletmeyle ilgili olarak düzenlendikleri55 ya da yabancı şirket ve kurumların, Türk şirketleri, kurumları ve bunlar haricindeki Türk tabiiyetindeki kișiler ile Devlet daireleri ve memurlarıyla olan hukuki ilişkilerde ${ }^{56}$ düzenlenen bonolardaki düzenleme yerinin Türkçe yazılması zorunluluğu hasıl olacaktır. Bono açısından kıymetli evrakın ortaya çıkış teorileri içerisinde hukuki görünüş teorisiyle tamamlanmış sözleşme teorisinin kabul edilmesi ${ }^{57}$ halinde söz konusu Kanun'un her iki hükmü açısından da bononun geniş anlamda muamele ${ }^{58}$ hem de dar anlamda sözleşme kavramı içerisinde değerlendirilmesi suretiyle düzenleme yerinin kaleme alınması açısından da Türkçe zorunlu dil olacaktır. Bu durumda, bu Kanun'un kapsamına giren kişilerin düzenleme yerini Türkçe kaleme almamaları halinde bu kişilere uygulanacak yaptırım söz konusu işlemin geçersizliği yerine Kanun'un 4. maddesi gereğince; bu kaydın sözleşmenin içeriğine dahil edilmemesidir ${ }^{59}$. Böyle bir durumda TBK

52 Bu hükümden hareketle kambiyo senetlerinin 805 sayılı Kanun'un kapsamına dahil edilemeyeceği yönündeki görüş için bkz. Murat Alışkan, "İktisadi Müesseselerde Türkçe Kullanma Zorunluluğu”, 2005, VIII(1-2), AÜEHFD, s. 360, <https://hukukdergi.ebyu.edu. $\operatorname{tr} / ? \mathrm{p}=1305>$ Erişim Tarihi 25.11.2020.

53 "Türk tabiiyetindeki her nevi şirket ve müesseseler, Türkiye dahilindeki her nevi muamele, mukavele, muhabere, hesap ve defterlerini Türkçe tutmağa mecburdurlar."

54 "Ecnebi Şirket ve müesseseler için bu mecburiyet Türk müessesatı ile ve Türkiye tebaasindan olan efrat ile muhabere, muamele ve temaslarina ve devair ve memurini Devletten birine ibraz mecburiyetinde bulunduklarl evrak ve defterlerine hasredilmiştir."

55 İsmail Kırca, "İktisadi Müesseselerde Mecburi Türkçe Kullanılması Hakkında Kanun Üzerine”, 2007, II, Prof. Dr. Hüseyin Ülgen’e Armağan, s. 1934-1935. Adi şirketin, özel hukuk hükümlerine göre yönetilmek veya ticari şekilde işletilmek üzere kamu tüzel kişileri tarafindan kurulan; ancak tüzel kişilikten yoksun olan işletmeler ile Türk tabiiyetindeki gerçek kişilere ait işletmelerin de bu hükmün kapsamı içerisinde olduğu yönünde bkz. Mehmet Bahtiyar, "805 Sayıl1, "İktisadi Müesseselerde Mecburi Türkçe Kullanılması Hakkında Kanun”un Kapsamı ve Yaptırımı Sorunu”, 2007, II, Prof. Dr. Hüseyin Ülgen’e Armağan, s. 1734-1735, 1736, 1737.

56 Kirca, s. 1938.

57 Bu konuda hakkında bilgi için bkz. Kendigelen/Kırca, s. 84.

58 Her ne kadar hükmün ikinci fikrasında birinci fikradan farklı olarak yalnızca 'muamele' ibaresine yer verilmişse de bunun sözleşmeleri de kapsadığı bir gerçektir. Bu yönde bkz. Bahtiyar, 805, s. 1739.

59 Kırca, s. 1940-1941. Bu konudaki ayrıntılı değerlendirmeler ve hükmün ispat niteliği taşıd1- 
m. 27/2-son cümlesi uygulanmayacaktır $\mathrm{ki}^{60}$, bono açısından ortaya çıkan hukuki boşluğun doldurulması -alternatif durum haricinde- işin doğasına aykırı olduğundan senedin geçersizliği gündeme gelecektir. Benzer durum, Kanun'un 3. maddesi ${ }^{61}$ açısından da geçerlidir. Diğer bir deyişle, hükmün Türkçe kaleme alınan metnin, yabancı dilde nüshası veya nüshaları söz konusu olduğunda, Türkçesine itibar edileceği şeklinde anlamlandırılması halinde $^{62}$ artık düzenleme yeri açısından belirlilik kalmadığından gene bono geçersiz olacaktır. Nihayetinde bonoda düzenleme yerinin kaleme alınmasında kullanılacak dil konusunda kural olarak bir serbesti var ise de, 805 sayıl1 Kanun'un uygulama alanına giren hallerde bu serbestinin rafa kaldırıldığını ve bonoda düzenleme yerinin tereddüde mahal vermeyecek şekilde ${ }^{63}$ Türkçe kaleme alınmasının zorunlu olduğu kabul edilmelidir.

\section{DÜZENLEME YERINE İLIŞKİN HÜKMÜN YERINDELİĞİ}

Bonoda düzenleme yerine ilişkin öngörülen TTK m. 777/4'te düzenleme yerinin yokluğu halinde alternatif unsur olarak “...düzenleyenin adının yanında yazılı olan yerde düzenlenmiş sayılır.” ifadesi karşısında doktrinde ileri sürülen bir görüş uyarınca ${ }^{64}$; senette geçerlilik şartı niteliğindeki zorunlu unsur olarak düzenleyenin imzası (TTK m. 776/1-g bendi) öngörüldügünden bahisle bu ibarenin "...düzenleyenin imzasinın yanında yazılı olan yerde düzenlenmiş sayılır.” şeklinde anlaşı1ması gerekir. Zira bu görüş uyarınca;

ğ1 yöndeki görüş için bkz. Bahtiyar, 805, s. 1745 vd.

${ }^{60}$ Benzer yönde bkz. Kırca, s. 1941-1942.

61 "İkinci maddede mezkür şirket ve müesseseler muamelatında Türkçeden başka bir lisanı dahi ilaveten kullanabilirlerse de asıl olan Türkçe olup mesul imzaların Türkçe metin zirine vaz'ı mecburidir. Bu memnuiyete rağmen imza diğer lisanla yazılmış kısım veya nüshanın altına mevzu olsa dahi Türkçesi muteberdir."

${ }^{62}$ Kırca, s. 1940. 3. madde 2. maddeyi tamamlayan bir hüküm niteliğindedir. Bkz. Bahtiyar, 805, s. 1740.

63 Düzenleme yeri açısından belirtilen mahalin aynı anlama gelecek şekilde Türkçe ve yabancı bir dilde kaleme alınmasının düzenleme yerinin geçerliliğine halel getirmeyeceğini söyleyebiliriz.

${ }^{64}$ Moroğlu, s. 512-513. Aynı yöndeki görüş için bkz. Şafak Narbay, "Türk Ticaret Kanunun Tasarısında Kıymetli Evrak Hukuku Kitabında Yapılan Düzenlemeler Ve Değişiklik Önerilerimiz", 2005, 7(Özel Say1), DEÜHFD, Prof. Dr. İrfan BAŞTUĞ Anısına Armağan, s. 200, <http://earsiv.erzincan.edu.tr/xmlui/bitstream/handle/20.50 0.12432/3313/\%c4\%b0RFAN\%20BA\%c5\%9eTU\%c4\%9e\%20ARMA\%c4\%9eANI. pdf? sequence=1\&isAllowed=y>, Erişim Tarihi 20 Kasım 2020; Bahtiyar, TBB, s. 99; Bozer/ Göle, s. 211; Özdamar/Göktürk/Can/Kaşak, s. 206. 'Adı' ifadesinin imzayı da kapsayacak şekilde geniş yorumlanması gerektiği görüşü için bkz. Kendigelen/Kırca, s. 176-177. 
mevcut düzenlemenin hükmün ratio legisine aykırı olduğu iddia edilmiştir. $\mathrm{Bu}$ görüşün doğru olmadığını hem hükmün önceki varyasyonlarına bakarak hem de mehazdaki düzenlemeler 1şı̆̆ında yorumlamak suretiyle söyleyebiliriz. Zira 865 sayılı TK m. 605/465 ile 6762 sayılı TTK m. 689/4 ${ }^{66}$ 'de benzer şekilde düzenlenmiştir. O halde kanun koyucunun iradesi, senedin alternatif şartı olarak öngördüğü düzenleme yeri açısından zorunlu ve mutlak bir kayıt olarak aranan düzenleyenin imzasına bağlamaya tercih etmeme yönündedir. Zaten aksi düşünce düzenleme yerinin yokluğundan bahisle bononun hiçbir surette geçersizliğinin ileri sürülemeyeceği anlamına gelir. Zira bonodaki imza her halükârda geçerlilik şartı olduğundan, bu görüş düzenleme yerinin alternatif şart olarak gösterilmesi düşüncesiyle çatışacaktır. Amaç alternatif unsuru zorunlu unsur harici kayitlarla destekleyerek bonoya kambiyo senedi vasfin1 vermektir. Diğer taraftan, OR Art 1097/4 ${ }^{67}$ ile WG Art 76/4 $4^{68}$ hükümlerinin birbirlerinin aynısı olduklarını ve bu düzenlemelerde TTK açısından da düzenleme yerinin yokluğu halinde alternatifi olarak düzenleyenin adl-Name ibaresine yer verildiğini görüyoruz. Haliyle 'Name' ibaresinin geniş yorumlanması suretiyle hükmün öngördüğü amacin hasıl olacağı söylenebilir. Zira tacirin ticaret unvanını serbestçe seçebileceği ve bu bağlamda bu adın kişi, konu, hayali veyahut karma bir ibare olabileceği kabul edilmektedir ${ }^{69}$. Buradan hareketle ad ibaresinin gerçek kişilerin adsoyadına, tüzel kişilerin ticaret unvanına ${ }^{70}$, tüzel kişi olmayan toplulukların

65 "Mahalli ihdası irae olunmayan emre muharrer bir senede sahibi imzanin ismi yaninda muharrer mahalde tanzim edilmis nazarile bakllır."

66 "Tanzim edildiği yer gösterilmiyen bir bono, tanzim edenin ad ve soyadı yanında yazılı olan yerde tanzim edilmiş sayılır." Burada yeni düzenleme karşısında düzenleyenin adının yanında soyadı ibaresinin de aranacağı ve ancak bu şekilde düzenleme yerinin kabul edileceği söylenecekti. Oysaki yeni düzenlemeyle sanki yalnızca gerçek kişilerin bu düzenlemede bulunabileceği veyahut ad ya da soyad ibarelerinden birisinin eksikliği halinde senedin bono vasfinı kazanamayacağı gibi abes bir durumla karşıya karşıya kalınacaktı. İşte bu yanlış düzenleme -üstelik 6762 sayılı TTK m. 584/4'te poliçeler bakımından keşidecinin soyadının yanındaki yer şeklinde ifade ediliyordu- mehazdaki düzenlemeyle uyumlu hale getirilerek doğru bir şekilde revize edildi.

67 "Ein eigener Wechsel ohne Angabe des Ausstellungsortes gilt als ausgestellt an dem Orte, der bei dem Namen des Ausstellers angegeben ist." Ayrıca bkz. Meier Hayoz/von der Crone, $\S 7$ (Art. 991 Ziff. 7 OR), Rn. 30, s. 128.

68 "Ein eigener Wechsel ohne Angabe des Ausstellungsortes gilt als ausgestellt an dem Orte, der bei dem Namen des Ausstellers angegeben ist."

69 Artur Teichmann, Handelsrecht, 3. Auflage, Nomos UTB, 2013, s. 233.

70 Düzenleyenin ticaret unvanına yer verilmesinin önemli olduğu tüzel kişinin temsilcisinin kendi hesabına mı yoksa tüzel kişinin hesabına mı imza attığının ve bu sayede işlemin ne şekilde bağlayıcılık kazanacağının belirlenmesi açısından vurgulanmıştır. Bkz. Moroğ- 
adına vb. şeklinde gönderme yaptığını söyleyebiliriz. Aksi halde 6762 sayılı TTK'da olduğu üzere mehaza aykırı bir yoruma gidilmiş olunur. Nitekim düzenleme yeri açısından tercih edilen ibarenin lehtar bakımından da aynı şekilde arandığı (TTK m. 776/1-e bendi) ve haliyle evleviyet gereği kanun koyucunun yapmış olduğu düzenlemenin başka bir şekilde anlaşılamayacağ 1 sonucuna ulaşılabilir. Zaten TTK m. 779/1 hükmünden hareketle TTK m. 671/1-c bendinin bonoya yansitılarak düzenleme yerindeki alternatif unsurun yerindeliğinin değerlendirilmesi bakımından kanun koyucunun iradesinin ne kadar doğru olduğunu görebiliriz.

\section{DÜZENLEME YERININ BELİRLİLIĞİ ESASINDA DİKKAT EDİLMESİ GEREKEN NOKTALAR}

\section{A) Genel Olarak}

Bonoda düzenleme yerinin hüküm altına alındığ1 TTK m. 776/1-f bendinde kullanılan 'yerini' ibaresinin tekil olmas1, düzenleme yerinin birden fazla gösterilmesine engel teşkil eder. Nitekim bonoda birden fazla düzenleme yerinin gösterilmesi TTK m. 777/4 hükmünün öngörülme mantığıyla tezat teşkil eder. Bu yüzden, düzenleyicisi tek olan bonoda birden fazla düzenleme yeri gösterilirse, bono geçersiz olur ${ }^{71}$. Bu takdirde aynı mantıktan hareket edilerek bonoda düzenleme yeri bir ve tek olacağına göre, düzenleme yerinin aslına ve alternatifine aynı anda senet metninde yer verilmesi halinde gene bono geçersiz olacaktır ${ }^{72}$. Şayet bononun birden fazla düzenleyicisi varsa birden fazla düzenleme yerinin tayin edilmiş olmasının bononun geçersizliğine yol açmayacağ 1 doktrinde ${ }^{73}$ ifade edilmektedir. Hatta Moroğlu'na göre ${ }^{74}$; birden çok düzenleyicisinin aynı veya farklı düzenleme yeri göstermeleri veyahut bunların soyadları ya da ad ve soyadları yanında aynı veya farklı yer adlarının

lu, s. 512. Ayrıca hükümdeki $a d \imath$ ibaresi amaca uygun surette geniş yorumlanacak olursa Moroğlu'nun “..., bono ile çekte ad ve soyadının yazılmamış olması durumunda imzasının yanında gösterilen yerin keşide yeri sayılıp sayılamayacağı duraksamasına da yol açılmış bulunmaktadir. Ancak hemen belirtelim ki, ratio legis'e aykırı bu duraksama yersizdir." ifadesi ete kemiğe bürünmüş olacaktır.

71 Aynı yöndeki görüş için bkz. Moroğlu, s. 511.

72 Benzer yönde bkz. Moroğlu, s. 511.

73 Bülow, WG Art 75, Nr. 6, Rn. 10, s. 348; Art. 1, Rn. 38, s. 24; Baumbach/Hefermehl, WG Art.1, Rn. 12, s. 115; BSK Wertpapierrecht- Grüninger/Hunziker/Roth, Art 991 OR, Rn. 22; Jacobi, § 48, s. 358 .

74 Moroğlu, s. 511. Aksi yöndeki görüş için bkz. Kendigelen/Kırca, s. 178. Senedin birden fazla kişi tarafından düzenlenmeyeceği yönünde bkz. Jacobi, § 48, s. 358-359. 
yazılı olması bononun geçersizliğine sebebiyet vermez. Bir kere, bu iddianın her durum için geçerli olmadığını bononun kamu güvenini haiz senetlerden ve sık1 şekil şartlarına tabi tutulmuş olmasından hareketle de söyleyebiliriz. Zira düzenleme yerinin tekliği esas olup, birden fazla düzenleme yerinin kararlaştırılmasının bononun birden fazla düzenleyicisi olduğu hallerde mümkün olduğu söylenebilirse de bu kişilerin aynı yeri düzenleme yeri tayin etmeleri halinde belirlilik sağlanacağından bononun geçerliliğine halel gelmeyecektir $^{75}$. Bu kabul, alternatif unsur açısından da geçerlidir. Oysaki bu kişilerin farklı yerleri göstermeleri -bonoda düzenleyenlerin sorumluluğu ödeme yeri hukukuna göre tayin edileceğinden (TTK m. 777/1-j bendinin yollamasiyla m. 770/1)- hem asli sorumluların hem de tali olarak sorumlu tutulanların farklı hukuki düzenlere tabi tutulması sonucunu doğuracağından düzenleme yerindeki belirsizlik bononun geçersizliğine vücut verecektir. $\mathrm{Bu}$ yüzden, düzenleyenlerin müşterek bir iradeyle hangi yerin bağlama kurallarına tabi olmak istiyorlarsa daha baştan bunu kararlaştırılmaları gerekir ${ }^{76}$; yoksa sonradan bu hukuk seçiminin yapılmasına izin verilmemelidir; meğerki kayıtsız şartsız tek bir ödeme vaadi ${ }^{77}$ söz konusu olsun. Bahsettiğimiz bu durumda vardığımız sonucun, şayet ödeme yerinin ${ }^{78}$ kararlaştırılmayıp TTK m. 777/3 hükmünün uygulama alanı bulduğu hallerde daha fazla önem kazandığg söylenebilir. Nitekim TTK m. 724/1 (TTK m. 778/1-d bendinin yollamasıyla) hükmü uyarınca; bononun birden fazla düzenleyeni söz konusu olduğunda, senet metnini ayrı ayrı imzaladıkları takdirde düzenleyenlerin müteselsil borçlu sıfatıyla sorumluluğundan bahsedilir. Pek tabidir ki, kanun hükmüne dayalı müteselsil borçluluk aynı sebepten (TBK m. 61/1 hükmünün birinci kısmı açısından) ileri geldiğinden artık düzenleme yerinin farklı yerler olarak tayini bonodaki taahhüdün geçersizliğine sebebiyet verir. Aksi düşünce, yalnızca müteselsil sorumluluğun aynı zarar için çeşitli sebeplerden ileri gelmesine bağlı olarak ortaya çıkabilirse de bono açısından bu olasılık söz konusu olmayacağı için bu duruma hiçbir istisna tanınamaz.

75 Çünkü bu durumda sözde birden fazla yer var iken, özde tek bir yer düzenleme yeri var olarak kabul edilmiştir. Benzer yöndeki görüş için bkz. Jacobi, § 48, s. 359.

76 Tek bir kambiyo senedinin düzenlenmesi ile birincil ve ikincil sorumluluk bakımından farklı bağlama noktalarının ayrı sorumluluklara yol açtığını, bu yüzden taraflara yeknesak bir uygulama için tek bir hukuk seçimi imkânı verilmesi gerektiği yönünde bkz. Bülow, WG Art. 93, Rn.4, s. 395.

77 Birden fazla düzenleyen açısından benzer yönde bkz. Bülow, WG Art. 1, Rn.42, s. 26.

78 Bonoda birden fazla ödeme yerinin tayini senedi geçersiz kılacaksa da (Bülow, WG Art. 1, Rn. 26, s. 21), aynı kabulün düzenleme yeri için geçerli olmadığı ifade edilmektedir. Bkz. Bülow WG Art. 1, Rn. 38, s. 24) 
Bonoda düzenleme yerinin mevcut bir yer olmas1 gerekir $^{79}$. Bununla birlikte bonoda düzenleme yeri fiilen düzenlendiği yerden başka bir yer olarak gösterilebilir ${ }^{80}$. Bu bağlamda bonoda düzenleme yerinin gerçeğe aykırı olması, düzenleme yerinin belirli olması kaydıyla bononun geçersizliğine sebebiyet vermez $^{81}$. Nitekim bononun Kayseri'de düzenlenip, bonoda düzenleme yerine Almanya yazılması bakımından senedin geçerliliği konusunda gerçek imza yeri mi yoksa bonoda gösterilen yerin mi esas alınacağı tartışmasında ${ }^{82}$ bononun hukuki niteliği ve amacı göz önünde tutularak senet üzerinde imza yeri olarak belirtilen yerin esas alınması gerekir. Zira 5718 sayıl1 MÖHUK'nı ${ }^{83} 7$. maddesinde yer alan hukuki işlemlerin işlemin yapıldığ 1 yer hukukuna tabi tutulmasına dair LRA (locus regit actum) kuralına o hukuki işlemin esasına uygulanan hukukun öngördüğü şekil kuralları (lex cause) ${ }^{84}$ ile bir istisna tanındığının göstergesidir. Zaten iradesini bononun düzenlendiği yer dışında farklı bir yerden yana kullanan kişinin düzenleyen sıfatıyla senedi

79 Rehfeldt/Zölnner, s. 58; Hueck, § 8, s. 39; Bülow, WG Art. 75, Rn.10; Moroğlu, s. 510; Kendigelen/Kırca, s. 177; Bozer/Göle, s. 210; Kendigelen, Çek, s. 121; Seza Reisoğlu, Çek Hukuku,1. Bası, Yazarın Kendi Yayını, 2011, s. 66-67. Hukuki ilişkinin korunması muhtemel bir yere dair bilginin varlığını gerektiriyorsa, senet metnindeki ifadenin doğru olmasının gerekmeyeceği yönünde bkz. Meier Hayoz/von der Crone, § 7 (Art. 991 Ziff. 7 OR), Rn. 30, s. 128. Benzer yönde bkz. Baumbach/Hefermehl, WG Art.1, Rn. 12, s. 115; Schoele, s. 6. Aksi halde geçersizlik gündeme geleceği yönünde bkz. Jacobi, § 48, s. 357. Aksi yöndeki görüş için bkz. Stanzl, s. 32.

80 Arslanlı, s. 63; Moroğlu, s. 510; Kınacıŏlu, s. 113; Kendigelen/Kırca, s. 177; Bozer/Göle, s. 210; Kendigelen, Çek, s. 121; Reisoğlu, s. 67. Kanunun düzenleme yerinin tespitinde farkl1 bir yol izlediği yönünde bkz. Jacobi, § 48, s. 356.

81 Arslanl1, s. 73; İmregün, s. 51; Moroğlu, s. 510; Kendigelen/Kırca, s. 177; BSK Wertpapierrecht- Grüninger/Hunziker/Roth, Art 991 OR, Rn. 22; Schoele, s. 6; J. Wiefels, Recht der Wertpapiere, 41.-43. Tausend Neu bearbeitetete Auflage, 9. Band, 1955, s. 49. Düzenleme yerine ilişkin bilgi imkânsız ya da tamamen olasılık dışı ise senede şüphe ile yaklaşılmalıdır. $\mathrm{Bu}$ cihetle bu duruma bir sınır getirilmesi gerekir: Düzenleme yeri mevcut değilse düzenleme yerinin mevcut olmadığı bilinmedikçe düzenleme yerinin varlığına halel getirmez. Bkz. Jacobi, § 48, s. 358 .

$82 \mathrm{Bu}$ tartışma hakkında ayrıntılı bilgi için bkz. Hatice Özdemir, "Kambiyo Taahhütlerinin Şekil Bakımından Geçerliliğine Uygulanacak Hukuk", 1999, İstanbul Üniversitesi Hukuk Fakültesi Eğitim-Öğretim ve Yardımlaşma Vakfı Yayınları No: 7, Prof. Dr. Nihal Uluocak'a Armağan, s. 262 vd. Ayrıca bkz. Cemal Şanlı/Emre Esen/İnci Ataman-Figanmeşe, 2. Bası, Milletlerarası Özel Hukuk, Vedat Kitapçılık, 2014, dipnot 4, s. 101. Doktrindeki görüşler için bkz. Poroy/Tekinalp, N.206, s. 154.

${ }^{83}$ RG, 12.12.2007, S: 26728, T: 5, C: 47.

${ }^{84}$ Bir hukuki işlemin yapıldı ğı yer hukukuna göre şeklen geçerli ise, o hukuki işlemin esasına uygulanan hukuk bakımından şeklen geçersiz olsa dahi Türk hukuku bakımından geçerli kabul edilmesi gerekir. Bkz.Şanlı, s. 99. 
o yerin kanunlarına tabi tutmak istediği anlamına gelir ${ }^{85}$. Bu husus devletler özel hukukundaki irade muhtariyetinin bir görünümüdür ${ }^{86}$. Bu sayede -gerçek imza yeri hukukunda farklı olarak- bononun tedavül güvenliği sağlanmış olur $^{87}$. Çünkü bonoyu iktisap eden üçüncü kişinin düzenleme yerine dair ifadelerin doğruluğu konusunda bir araştırma yapması gerekmez ${ }^{88}$.

\section{B) Düzenleme Yerinin İdari Birim Olması Zorunluluğu}

Bonoda düzenleme yerinin nasıl ve ne şekilde belirleneceği konusunda TTK'da yol gösterici bir hüküm olmadığı için düzenleme yerindeki belirliliğinin nasıl sağlanacağına dair bir kriterin benimsenmesi zorunluluğu vardır. $\mathrm{Bu}$ yüzden, öncelikle doktrindeki görüşlere yer verilerek, giderek Yargıtay'ın verdiği kararlar irdelenmek suretiyle bu konudaki görüşümüzü dile getireceğiz.

Doktrinde Öztan, düzenleme yerinin belli ve mümkün olması kaydıyla geçerli olacağını ve muhakkak mülki birlik ismi olması gerektiğini dile getirmektedir $^{89}$. Bu yüzden, düzenleme yeri idari birim olarak kent, ilçe, köy, bucak adı olabilir ${ }^{90}$. Bunun haricinde adres gösterilmesi zorunluluğu yoktur ${ }^{91}$. Oysaki Bozer/Göle, düzenleme yerinin idari birim kavramıyla sınırlandırılmasının yoğun mesai gerektiren ve zaman kaybına yol açan bir araştırma faaliyetine sebebiyet vereceğinden ve bononun tedavül kabiliyetini zayıflatacağından ötürü doğru olmadığını dile getirmektedirler ${ }^{92}$. Pulaşlı ise tam aksine düzenleme yerinin belli olmasının yanı sıra bir mülki birliğin ismi olması gerektiğini; ancak il ve ilçe dışında semt ya da meydan adlarının bu

Arslanl1, s. 63. Aynı yöndeki görüş için bkz. Moroğlu, s. 510.

86 Arslanli, s. 63.

87 Özdemir, s. 267. Ayn1 yöndeki görüş için bkz. Moroğlu, s. 510.

88 Hueck, § 8, s. 39; Özdemir, s. 267; Moroğlu, s. 510.

89 Öztan, s. 83; Özdamar/Göktürk/Can/Kaşak, s. 206. Çek açısından aynı yöndeki görüş için bkz. Reisoğlu, s. 66-67. Poliçe açısından keşide yerinin muhakkak bir mahalli göstermesi gerektiği yönünde bkz. Kınacıŏglu, s. 113.

90 Kendigelen/Kırca, s. 177; Ülgen/Helvac1/Kaya/Nomer Ertan, 146. Çekler açısından bkz. Kendigelen, Çek, s. 118. Semt adının düzenleme yeri olamayacağı yönünde bkz. Ülgen/ Helvaci/Kaya/Nomer Ertan, s. 146.

91 Kendigelen/Kırca, s. 177; Ülgen/Helvacı/Kaya/Nomer Ertan, s. 146; Özdamar/Göktürk/ Can/Kaşak, s. 206.

92 Coğrafi birim olmayan neresi olduğu tespit edilemeyen çalışma ofisim ya da dükkanım şeklinde ifadelerin bononun geçersizliğine sebebiyet vereceği yönünde bkz. Bozer/Göle, s. 211212. 
kapsamın dışında kaldığını dile getirmektedir ${ }^{93}$. Kayar ise düzenleme yerinin il, ilçe veya köy adı olarak idari birim şeklinde gösterilebilmekle birlikte Taksim, Ulus, Şirinyer gibi mülki birimleri ifade etmeyen; ancak herkesçe bilinen bu yerlerin ilçe esas alınarak düzenleme yeri olarak kabul edilmesi gerektiğini savunmaktadır ${ }^{94}$.

Narbay ise bir yerin bağlı bulunduğu yer gösterilmeksizin her yerde bulunması muhtemel olan bir mahalle, semt adı, belde veya köy adının veyahut aynı adı taşıyan ve farklı illere ait olan ilçelerin yazılmasının geçerli bir düzenleme yeri teşkil etmediğini çekler açısından kabul etmektedir ${ }^{95}$.

Moroğlu ${ }^{96}$ ise düzenleme yerinin tüzel kişiliği haiz olmasa da bir yönetim birimin coğrafi adı olarak tespit edilmesi gerekliliğinden bahsetmektedir. $\mathrm{Bu}$ bağlamda il, ilçe, bucak, köy ve mahalle adları idari birim olarak coğrafi ad olmalarından ötürü geçerli düzenleme yeri olarak kabul edilebilir. Oysaki cadde, sokak ve semt adları ile Van Gölü, Fırat Havzası, Uzunyayla, Çamkoyu, Gemlik Körfezi, Ölüdeniz ${ }^{97}$ gibi coğrafi adlar idari birim olmadıkları gerekçesiyle düzenleme yeri olarak kabul edilemezler. Uyar ${ }^{98}$ ise tam aksine bonoda düzenleme yerinin bir idari birim olması gerektiğini, idari birim olmayan yerlerin ve yalnızca mahalle ve sokak adlarının yazılmasının düzenleme yeri olarak kabul görmeyeceğini dile getirmektedir.

Yargitay ise vermiş olduğu bir kararda"99; "Köy mahalli idareler ayrımına göre bir birim olup senette gösterilmesi halinde, TTK.nun 688/6 maddesinde belirtilen tanzim yerinin varlı̆̆ karşısında, diğer unsurlarl tamam olan senedin, kambiyo senedi saylması zorunludur." şeklindeki ifadeyle bonoda düzenleme yerinin köy olabileceğini kabul etmiştir. Hatta bu kararda; "Mercice

93 Pulaşl1, s. 140.

94 Kayar, s. 129-130.

95 Şafak Narbay, "Çekte İbraz Sürelerinin Belirlenmesinde Ölçü Alınan "Yer” Kavramına "De Lege Lata" ve "De Lege Ferenda" Çözüm Önerileri”, 2003, I, Bilgi Toplumunda HukukÜnal Tekinalp'e Armağan, s. 814.

96 Moroğlu, s. 512-513. Poliçe ve bonolar bakımından hukuk güvenliğini zedelemeyecek olan bu görüşün çekler açısından şüphe ile karşılanacağı hususunda bkz. Kendigelen, Çek, s. 120.

97 Ölüdeniz açısından verilen örneğin doğru olmadığını; bunu coğrafi bir ad olarak düşünülmeyip Muğla-Fethiye'ye bağlı bir mahalle adı olarak geçerli bir düzenleme yeridir.

98 Uyar, TBB, s. 312 ve 313; Uyar, s. 34.

99 Y. 12. HD., 14.12.1998, E.1998/12925, K. 1998/14422<https://karararama.yargitay.gov.tr/ >Erişim Tarihi 20 Aralık 2020. Aynı yöndeki (Y. 12. HD., 14.06.2001, E. 2001/9746, K. 2001/10652) ve bu karar için bkz. Narbay, Armağan, s. 812. 
sadece IIller İdaresi Kanunundaki ayrımı esas alarak takip dayanağı belgelerin bono niteliğinde olmadiğı şeklindeki gerekçesi yerinde görülmediğinden merci kararı anılan senet yönünde bozulması gerektiği sonucuna varılmıştır." yönündeki ifadesiyle de idari birim kavramının içeriği doldurulmuştur.

Yargıtay'ın kararlarına sırasıyla bakıldığında'00; "Düzenleme (keşide) yerinin hiçbir duraksamaya yer vermeyecek ve başka yerleşim yerlerini çağrıştırmayacak biçimde açık, net ve herkes tarafindan anlaşılabilir şekilde gösterilmesi gerekir. Suça konu bonoda ise, açıkça düzenleme yeri belirtilmemiş olup, senedi düzenleyenin ismi altında "Dikmen" biçiminde gösterilen adres hiçbir kuşku ve duraksamaya yer vermeyecek biçimde anlaşılabilir bir idari birim adını ifade etmeyip, kefil adının yanında "Gölbaşı" ibaresinin yazılı olmasının da suça konu senedin bono sayılabilmesi için gerekli olan unsurlardan "düzenleme yeri" unsurunu tamamlayamayacağ $l$ "101;

“...bonoda açıkça düzenleme yerinin belirtilmediği, senet borçlusunun ismi altında "adlan ... ..." şeklinde gösterilen adresin de hiçbir kuşku ve duraksamaya yer vermeyecek biçimde anlaşılabilir bir idari birim adını ifade etmediği..."102;

“...bonolart düzenleyenin ismi altında "Kocaali Köyü” biçiminde bir adres gösterilmiştir. Bu adres hiçbir kuşku ve duraksamaya yer vermeyecek biçimde anlaşllabilir bir idari birim adını ifade etmemektedir. Ayrıca keşide tarihi de yazılmamıştır. Bu itibarla, suça konu senedin bono vasfinı taşımadi $\breve{g} l . . . " l 03$;

“...suça konu senedin düzenleme yerinin yazmadı̆ğ, borçlu ismi yanındaki adres kısmında da idari birim olarak ANT yazdiğı, bunun geçerli bir düzenleme yeri olarak kabul edilemeyeceği ... "104;

“...idari birim sayllacak bir yerin de belirtilmemesi karşısında;

${ }^{100}$ Düzenleme yeri köy değil de mahalle ise geçerli bir düzenleme yerinden bahsedilemez. Bkz. Eriş, s. 587-588.

${ }^{101}$ Y. 11. CD., 16.12.2019, E. 2017/16964, K.2019/9496 <https://karararama.yargitay.gov.tr/ >Erişim Tarihi 20 Aralık 2020.

${ }^{102}$ Y. 11. CD., 16.09.2019, 2019/1781, K. 2019/6297<https://karararama.yargitay.gov.tr/ > Erişim Tarihi 20 Aralık 2020.

${ }^{103}$ Y.11.CD., 25.06.2019, 2019/3896, K. 2019/5630 <https://karararama.yargitay.gov.tr/ > Erişim Tarihi 20 Aralık 2020.

${ }^{104}$ YCGK, 21.05.2019, 2018/171, K. 2019/453 <https://karararama.yargitay.gov.tr/ > Erişim Tarihi 20 Aralık 2020. 
senedin bono niteliğini taşımadiğg ..."

“...Düzenleme yeri olarak, idari birim adı (kent, ilçe, bucak, köy gibi) yazılması yeterli olup, ayrıca adres gösterilmesi zorunluluğu bulunmamaktadır..."106;

“...takip dayană̆ edenin adı ve soyadı yanındaki adreste de idari birim yazılı değildir... "107;

“...Hukuk Genel Kurulu'nun 02.10.1996 gün ve 1996/12-590 sayılı kararında da benimsendiği üzere tanzim yeri olarak idari birim adının (kent, ilçe, bucak, köy gibi) yazılması zorunlu ve yeterlidir..."108;

“...TTK’nun 777. maddesine göre bu eksikliğin düzenleyenin isminin yanında yer alan ve Idaribirimi ifade eden adres bilgisi ile tamamlanabileceği ... "109;

“...Somut olayda, takibe dayanak senedin düzenleme yeri içermediğ $i$ sadece 'camiikebir mah.' şeklinde bir ibare içerdiği, düzenleyenin adının

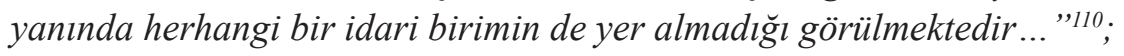

“...Dosya içerisinde örneği bulunan suça konu bonolarda açıkça düzenleme yeri belirtilmemiş, bonoları düzenleyenin ismi altında "Natoyolu Cad..." biçiminde bir adres gösterilmiştir. Bu adres hiçbir kuşku ve duraksamaya yer vermeyecek biçimde anlaşılabilir bir idari birim adını ifade etmemektedir. Bu itibarla, suça konu senedin bono vasfinı taşımadiğ

${ }^{105}$ Y.11.CD., 19.02.2019, E. 2018/6811, K. 2019/1632 <https://karararama.yargitay.gov.tr/ >Erişim Tarihi 20 Aralık 2020.

${ }^{106}$ Y.12.HD., 24.01.2019, E.2018/11556, K. 2019/1050 <https://karararama.yargitay.gov.tr/ $>$ Erişim Tarihi 20 Aralık 2020.

${ }^{107}$ Y.12.HD., 22.11.2018, E.2017/6337, K. 2018/12027 <https://karararama.yargitay.gov.tr/ $>$ Erişim Tarihi 20 Aralık 2020.

${ }^{108}$ Y.12.HD., 02.07.2018, E.2017/5880, K. 2018/7116 <https://karararama.yargitay.gov.tr/ >Erişim Tarihi 20 Aralık 2020.

${ }^{109}$ Y.12.HD, 31.05.2018, 2018/9648, K.2018/5675 <https://karararama.yargitay.gov.tr/ > Erişim Tarihi 20 Aralık 2020.

${ }^{110}$ Y.12.HD., 20.03.2018, E.2018/1755, K. 2018/2819 <https://karararama.yargitay.gov.tr/ >Erişim Tarihi 20 Aralık 2020.

${ }^{111}$ Y.11.CD.,18.12.2017, E. 2017/4441, K. 2017/9040 <https://karararama.yargitay.gov.tr/ >Erişim Tarihi 20 Aralık 2020.

184 Ankara Hacı Bayram Veli Üniversitesi Hukuk Fakültesi Dergisi C. XXV, Y. 2021, Sa. 2 
“...Dosyada bulunan bono suretinin incelenmesinde, borçlu adresinin “.....” olarak gösterildiği, .... 'nın bononun düzenlendiği 10.08.2009 tarihinde .... Illi .... Illçesine bağll belde niteliğinde olup belde belediyesinin bulunduğu, 06.12.2012 tarihli Resmi Gazetede yayımlanan 6360 sayll yasa ile Ayaslar Beldesi'nin belde niteliğinin kaldirllarak mahalle statüsü kazandiğ ve suça konu bononun düzenleme yeri olarak “....” şeklindeki isminin gösterilmesi sebebiyle senedin yasal unsurlarının tam olduğu anlaşılmıştır ..." "II2,

"...senedi düzenleyen ismi altında "Ayaslar Kasabası" biçiminde bir adres gösterilmiştir. Bu adres hiçbir kuşku ve duraksamaya yer vermeyecek biçimde anlaşılabilir bir idari birim adinı ifade etmemektedir. ... "Il3;

“...belde olup, senedin düzenleme tarihi olan 05.10.2008 tarihinde halen belde statüsünü koruduğundan, düzenleme yerinin bulunduğunun kabulü için zorunlu olan idari birim niteliği taşımaktadır..."II4;

"...senedi düzenleyen ismi altında da "H.kavak" biçiminde bir adres gösterilmiştir. Bu adres hiçbir kuşku ve duraksamaya yer vermeyecek biçimde anlaşılabilir bir idari birim adını ifade etmemektedir..." ${ }^{115}$;

“...Somut olayda, takibe dayanak yapılan senetlerde TTK'nun 776/1-f maddesinde zorunlu kllınan tanzim yeri bulunmadiğl, tanzim edenin adı soyadl altında yazllı olan "...... Sok 3/A” ve "... Mah ... . Sok 3/A "adresinin belirgin bir idari birimi belirtmediği anlaşıldiğından, TTK'nun 776/1-f maddesinde öngörülen koşulun oluşmadığı sonucuna varılmalıdır..."

“...Somut olaya bakıldı̆̆ında, takip dayanağ senette düzenlenme yerinin olmadiğl, düzenleyenin adl soyadı altında yazılı olan "Halkalı Atatürk Mah. Kiptaş Konut A-11 Halkalı" adresinin belirgin bir idari birimi belirtmediği ve dolaylstyla düzenlenme yeri olarak kabulünün mümkün

112 Y.11.CD., 21.11.2007, E.2017/15877, K. 2017/8009 <https://karararama.yargitay.gov.tr/ >Erişim Tarihi 20 Aralık 2020.

${ }^{113}$ Y.11.CD., 19.09.2017, E. 2015/4807, K. 2017/5760 <https://karararama.yargitay.gov.tr/ >Erişim Tarihi 20 Aralık 2020.

${ }^{114}$ Y.12.HD., 08.06.2017, E.2017/3389, K. 2017/8975 <https://karararama.yargitay.gov.tr/ >Erişim Tarihi 20 Aralık 2020.

115 Y.11.CD., 06.06.2017, E. 2015/3880, K. 2017/4207 <https://karararama.yargitay.gov.tr/ >Erişim Tarihi 20 Aralık 2020.

116 Y.12.HD., 15.12.2016, E. 2016/7301, K. 2016/25641 <https://karararama.yargitay.gov.tr/ >Erişim Tarihi 20 Aralık 2020. 


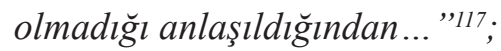

"..."mahalle" nin idari birim olarak kabulüne yasal imkan bulunmamakta...Somut olayda, takibe konu senette yazılı olan "Kizlltoprak" mahalle adı olup yasanın aradı̆̆ anlamda bir idari birim olmadı̆̆ından... "118;

"...düzenleyenin adl soyadı altında yazılı olan "Cambaziye Mektep sok. Yokuş Apt. No: 49/4 Kocamustafapaşa” adresinin belirgin bir idari birimi belirtmediği ..." "119;

“...senet borçlusunun ismi altında "GMK Bulvarı 118/6 Tandoğan Maltepe" şeklinde gösterilen adresin de hiçbir kuşku ve duraksamaya yer vermeyecek biçimde anlaşılabilir bir idari birim adını ifade etmediği..." 120 şeklindeki ifadelerle düzenleme yerine ilişkin bir birliktelikten bahsedilebilir.

Görüldüğü üzere; Yargitay Hukuk Genel Kurulu'nun 02.10.1996 gün ve 1996/12-590 sayılı kararında da benimsendiği üzere, tanzim yeri olarak idari birim adının (kent, ilçe, bucak, köy gibi) yazılması gerekli ve yeterli olup, ayrıca adres gösterilmesi zorunluluğu bulunmaması görüşü Yargıtay'ın son zamanlarda verdiği kararlarda yeknesaklık kazanmıştır.

Bonoda düzenleme yerini belirlerken şirketin merkezi kavramından yola çıkılması gerekir ${ }^{121}$. Her nedense düzenleme yerini belirlerken hangi kıstastan hareket edilmesi gerektiği konusunda bir kaynak araştırması yapılmadığını görmekteyiz. Oysaki bilhassa bononun kullanılma amac1 göz önüne alındığında tacirlerin daha çok kambiyo senetlerindeki kredi işlevinden istifade etmeye çalıştıklarını söyleyebiliriz. Haliyle şirketin merkezi kavramının

117 Y.12.HD., 28.04.2016, E.2016/57, K. 2016/12569 < https://karararama.yargitay.gov.tr/ > Erişim Tarihi 20 Aralık 2020.

118 Y.12.HD., 15.04.2014, E. 2014/8452, K. 2014/10930 <https://karararama.yargitay.gov.tr/ >Erişim Tarihi 20 Aralık 2020.

119 Y.12.HD., 01.03.2018, E. 2016/219714, K. 2018/2165 <https://karararama.yargitay.gov.tr/ >Erişim Tarihi 20 Aralık 2020.

${ }^{120}$ Y.11.CD., 03.02.2020, E. 2017/14477, K. 2020/756 <https://karararama.yargitay.gov.tr/ >Erişim Tarihi 20 Aralık 2020.

${ }^{121}$ Zaten aranılacak borç söz konusu olduğu için borçlunun ikametgahında ya da iş yerinde ifası gerektiğinden bahisle kambiyo senetlerine özgü olarak şirket merkezi kavramı esas alınması gerektiği sonucuna da dolayısıyla ulaşılabilir. Aynı zamanda TTK m. 777/3'teki hüküm de bu görüşümüzü desteklemektedir.

186 Ankara Hacı Bayram Veli Üniversitesi Hukuk Fakültesi Dergisi C. XXV, Y. 2021, Sa. 2 
birçok yönden sahip olduğu önemi ve işlevinin ${ }^{122}$ bonodaki düzenleme yeri ile benzerlik arz ettiğini ve bu durumun -esasında şirket merkezi kavramı belirlenirken kullanılan irade muhtariyetinin- bonodaki düzenleme yeri için de geçerli olduğunu evleviyetle kabul edebiliriz. Bu yüzden merkezin, açık bir şekilde il veya ilçe (mülki birlik) olarak belirtilmesi gerektiği; ancak ayrıca bir adres gösterilmesine gerek olmadığı kabul edilmektedir ${ }^{123}$. Buradan hareketle bonoda düzenleme yerinin mülki idari birim olması gerektiği ${ }^{124}$ kural olarak söylenebilir.

Mülki idari birimlerden ne anlaşılacağı konusunda idare hukukundaki yerinden yönetim ilkesinden yola çıkılmalıdır. Bu bağlamda Anayasa'nın ${ }^{125}$ 127. maddesinin birinci fıkrası hükmü uyarınca; "Mahalli idareler; il, belediye veya köy halkının mahalli müşterek ihtiyaçlarını karşılamak üzere kuruluş esasları kanunla belirtilen ve karar organları, gene kanunda gösterilen, seçmenler tarafindan seçilerek oluşturulan kamu tüzelkişileridir." Zaten 5442 sayıl1 Kanun'un 1. maddesinin birinci fikrası uyarınca; "Türkiye merkezi idare kuruluşu bakımından coğrafya durumuna, iktisadi şartlara ve kamu hizmetlerinin gereklerine göre illere; iller ilçelere ve ilçeler de bucaklara bölünmüştür." Ayrıca İl İdaresi Kanunu'nun 3. maddesinin ikinci fikras1 hükmü uyarınca; "Illlerde genel idare teşkilatı il, ilçe ve bucak bölümlerine uygun olarak düzenlenir." O halde bonoda düzenleme yerinin kural olarak il ve ilçelerden ${ }^{126}$ oluşacağ 1 kabul edilmelidir. Ancak 6360 sayılı Kanun'un ${ }^{127}$ 1. maddesinin 6.fikrası hükmü ile illerin bucakları ve bucak teşkilatları kaldırıldığından ${ }^{128}$ artık bucakların bonoda düzenleme yeri olmasından bahsedilemeyecektir. Beldeler açısından konuya yaklaşıldığında ise 6360

${ }^{122} \mathrm{Bu}$ konu hakkında ayrıntılı bilgi için bkz. Mehmet Bahtiyar, Anonim Ortaklık Anasözleşmesi, 1. Bas1, Beta Yayınc1lık, 2001, s. 113.

${ }^{123}$ Bahtiyar, Anasözleşme, s. 112.

${ }^{124}$ Mülki idari birim olarak gösterilen yerin alışılageldik şekliyle kullanılması yeterlidir. Bu adın resmi makamların nitelendirilmesiyle uyuşması gerekmez. Hatta sınırları belirtilmemiş yerlerin de alışılageldik bir nitelendirmeyi ihtiva etmediği gerekçesiyle düzenleme yeri olarak kabul edilememesi gerekir. Bkz. Jacobi, § 48, s. 355-356.

${ }^{125}$ RG, 9.11.1982, S: 17863 (Mükerrer), T: 5, C: 22.

126 İdari teşkilata ilişkin 6360 sayılı Kanunla yapılan değişiklikler hakkında ayrıntılı bilgi için bkz. Tahiroğlu, s.62 vd.

127 RG, 6.12.2012, S: 28489, T: 5, C: 53.

${ }^{128} 6552$ sayıl1 Kanunun 129. maddesi ile 5747 say1l Kanunu'nun 2.maddesinin dokuzuncu fikrasının değiştirilmesi sonucunda merkezi idarenin taşra teşkilatı yalnızca il ve ilçe idarelerinden teşekküle etmektedir. Bkz. Tahiroğlu, s. 72. 
sayı1ı Kanun'un 1. maddesinin üçüncü fikrası ile belde belediyelerin varlığına son verilmesi suretiyle bunları bağlı oldukları ilçenin belediyesine bağlanması sağlanmıştır ${ }^{129}$. Bu sefer köy idareleri açısından konuya yaklaşıldığında ise öncelikle Anayasamız bağlamında Türkiye'de köylerin de tüzel kişiliğe sahip üç ayrı mahalli idareden birisi olduğu dile getirilmektedir ${ }^{130}$. Bununla birlikte 6360 sayılı Kanun'un 1. maddesinin üçüncü fikrasında köylerin tüzel kişiliği kaldırılarak, mahalle olarak bağlı bulundukları ilçelerin belediyesine katılmışlardır. Hatta hükmün dördüncü fikrası ile de İstanbul ve Kocaeli il mülki sınırları içerisinde bulunan köylerin tüzel kişiliği kaldırılarak bağlı bulundukları ilçe belediyesine mahalle olarak katılmışlardır. Böylelikle büyükşehir belediyesi bulunan yerlerdeki tüm köylerin varllğ 1 sona ermiştir ${ }^{131}$. $\mathrm{O}$ halde köylerin bonoda düzenleme yeri olarak kabulü mümkün ise de bu sayının azalacağı evleviyetle söylenebilir. Son olarak ise mahallenin bonoda düzenleme yeri olup olmayacağı tartışılmalıdır. 5393 sayılı Kanun'un ${ }^{132} 3$. maddesinin d bendi uyarınca; belediye sınırları içinde, ihtiyaç ve öncelikleri benzer özellikler gösteren ve sakinleri arasında komşuluk ilişkisi bulunan idari birimi ifade eden mahallelerin tüzel kişiliğe sahip olmasalar da 6360 sayılı Kanun ile köylerin kaldırılmasına ilişkin düzenlemeye yönelik eleştiriler bir yana birakılacak olursa ${ }^{133}$, bonoda düzenleme yeri olarak kabulünü gerektirir. Çünkü bazı köylerdeki köy mahalli idarelerin varlığına son verilmesi halinde bu köylerin mahalli müşterek ihtiyaçlarının başka bir mahalli idare tarafından karşılanmasında hukuka aykırılık yoktur ${ }^{134}$. Zaten halihazırda belediye sınırları içinde nüfusu 500'ün altında mahalle kurulamadığı gibi, (6360 sayılı Kanun'un 15. maddesi ile yapılan değişiklik sonucunda 5393 sayılı Kanun'un 9. maddesinin üçüncü fikrasının son cümlesi uyarınca) tüzel kişiliği kaldırılan köylerin nüfusu 500'ün altında olsa bile bu yerler mahalleye dönüşeceği için ${ }^{135}$

${ }^{129} 6360$ sayılı Kanunu'nun 1.maddesinin üçüncü fikrası sonucunda bkz. Tahiroğlu, s. 73 vd.

${ }^{130}$ Kemal Gözler, “6360 Sayılı Kanun Hakkında Eleştiriler (Yirmi Dokuz İlde İl Özel İdareleri ve Köylerin Kaldırılması ve İlçe Belediyelerinin Büyükşehir İlçe Belediyesi Haline Dönüştürülmesi Anayasamıza Uygun Mudur?”, 2013, 11(122), Legal Hukuk Dergisi, s. 2 ve $5<$ https://www.idare.gen.tr/6360-elestiriler.pdf > Erişim tarihi 20.11.2020.

131 Tahir Muratoğlu, "Mahalli İdareler Mevzuatında 6360 Sayılı Kanunla Yapılan Değişiklikler”, 2015, 20(32), Dicle Üniversitesi Hukuk Fakültesi Dergisi, s. 77 <https://dergipark.org.tr/tr/ pub/duhfd/issue/23032/246225> Erişim Tarihi 20.11.2020.

${ }^{132}$ RG, 13.07.2005, S: 25874, T: 5, C: 44.

${ }^{133}$ Gözler, s. 5 vd.; Muratoğlu, s. 77 vd.

${ }^{134}$ Muratoğlu, s. 79.

${ }^{135}$ Muratoğlu, s. 81.

188 Ankara Hacı Bayram Veli Üniversitesi Hukuk Fakültesi Dergisi C. XXV, Y. 2021, Sa. 2 
köylerin mahalleyi ikamesi sonucunda mahallenin de evleviyetle bonoda düzenleme yeri olarak kabulünü gerektirir. Bu yüzden bonoda düzenleme yeri açısından tüzel kişiliği olan idari birim kavramına istisna tanınarak mahallelerin bu kapsama dahil edilmesi gerekir ${ }^{136}$. Oysaki semt, cadde ile sokak adlarının ${ }^{137}$ bonoda düzenleme yeri olarak kabulü mümkün değildir. Zira bu yerleşim adlarının düzenleme yerindeki belirliliği azami düzeyde ortadan kaldıracağını ve bu gibi yerlerin düzenleme yeri olarak kabulünün idari teşkilata dair yapılan düzenlemelerin öngörülme amacına aykırılık teşkil edeceğini söyleyebiliriz.

Yapılan bu tartışmalar 1şığında şayet bonoda düzenleme yerine ilişkin bir ihtilaf çıkacak olursa, söz konusu uyuşmazlığa bakan hâkimin re'sen Türkiye Mülki İdare Bölümleri Envanteri'nden ${ }^{138}$ il, ilçe, köy ve mahalle bazında yapacağı araştırma neticesinde düzenleme yerinin geçerli olup olmadığına ve haliyle diğer şartlar da varsa bononun geçerli olup olmadığı konusunda bir karar verebilecektir. Ayrıca yapılan bu tartışmaları en aza indirgemek maksadıyla bonodaki düzenleme yeri yazılırken bu yerin (il ve ilçe haricinde) bağlı olduğu il ya da ilçenin gösterilmesi tavsiye edilebilir.

\section{C) Düzenleme Yerinin Kısaltılarak Yazılabilmesi Sorunsalı}

TTK' da bonoda düzenleme yerini hem asli hem de alternatif unsuru olarak kısaltılarak yazılıp yazılmayacağı konusunda herhangi bir düzenleme söz

${ }^{136}$ Çek hukuku açısından benzer yöndeki görüş için bkz. Sercan Uçar, "6360 Sayılı Büyükşehir Kanun Hükümleri Ișı ğında Çekte "Düzenlenme Yeri” ve "İbraz Süresi” Kavramları Üzerine Bazı Tespit Ve Değerlendirmeler", 2019, 31(140), TBB, s. 341 vd. <http://tbbdergisi. barobirlik.org.tr/m2019-140-1824> Erişim Tarihi 20.11.2020. Nitekim Kendigelen de çekler bakımından mahallenin düzenleme yeri olarak kabulü noktasında ibraz sürelerinin hesaplanmasında karışıklıklara sebebiyet vereceğinden bahisle tereddütle yaklaşılması gerektiğini ifade etse de, bu durumun poliçe ve bono açısından hukuki güvenliği zedelemeyeceğini kabul etmektedir. Bkz. Kendigelen, Çek, s. 120. Bu yöndeki görüşü destekleyen genel geçer ifade için bkz. Jacobi, § 48, s. 355 .

${ }^{137}$ Açık ve anlaşı1ır olmadığ 1 gibi sokak adının düzenleme yeri olmayacağı hususunda bkz. Jacobi, § 48, s. 355 .

$138<$ https://www.e-icisleri.gov.tr/Anasayfa/MulkiIdariBolumleri.aspx.>Erişim tarihi 16.12.2020. Ayrıca İçişleri Bakanlığı İller İdaresi Genel Müdürlüğünce, ülkemiz mülki idari sınırlarına dair coğrafi veri tabanlı harita üretim tekniklerine ve konumlama sistemlerine uygun şekilde idari birim sınırlarını sayısallaştırılmasını amaçlayan "Mülki İdari Sınırların Güncellenmesi ve Sayısallaştırılması Projesi (MIDAS)" hayata geçirilmiştir. Bunun için bkz. <https://www.icisleri.gov.tr/illeridaresi/idari-sinirlarin-guncellenmesi-vesayisallastirilmasi-projesi-isgsp. > Erişim Tarihi 16.12.2020. Böylelikle illere, ilçelere, köylere ve mahallelere dair bir veri tabanı ile bonoda düzenleme yerinin azami düzeyde belirlilik kazanacağı ve yapılan hukuki tartışmaların da bu sistem sayesinde en aza indirgenebileceği söylenebilir. 
konusu değildir. Haliyle bonoda düzenleme yerine dair kısaltmaya uygulamada ziyadesiyle fazla karşılaşılması neticesinde ve işlemleri olabildiğince ayakta tutma prensibi çerçevesinde bu tür kayıtların geçerliliği ve buna dair bir kıstasın ne olabileceği sorunsalının çözümlenmesi gerekir. Yargıtay İçtihadı Birleştirme Genel Kurulu'nun 14.12.1992 gün ve E.1992/1, K. 1992/5 say1l1 karar $1^{139}$ ile çeklerde keşide yerinin, hiçbir duraksamaya yer vermeyecek şekilde anlaşılabilir olması koşulu ile kısaltılmış olarak yazılması halinde, çekin sadece keşide yerinin kısaltılmış olarak yazılmış bulunması sebebiyle geçersiz sayılamayacağına karar verilmiştir. Bu karar alınırken gerekçe şu şekilde ifade edilmiştir: "Keşideci çeki düzenlemekle o konudaki iradesini beyan etmiş olmaktadır. İrade beyanı olmadan çekin vücut bulması mümkün değildir. Bu irade beyanının anlaşılır olması en önemli özelliğidir. Kanun beyan için yazılı olması dışında başkaca bir şekil şartı koymamıştır. Çekin bu niteliği dikkate alındı̆̆ında, keşidecinin çekte kısaltma kullanmasını engelleyen bir düzenleme olmadı̆̆ söylenebilir. Bunun gibi keşide yerinin yazılması da bir irade beyanı olduğundan anlaşılabilir olması koşulu ile bu irade beyanının kısaltılarak yazılması da mümkündür. Okunduğunda hiçbir duraksamaya söz konusu olmaksızın anlamları belirlenebilen kısaltmaların keşide yeri olarak yazılması çeki sadece bu kısaltma sebebiyle geçersiz hale getirmez. G.Antep, Ş. Urfa, K. Maraş, G.Hacıöy, Ş.Koçhisar ve Ş.Karahisar gibi kisaltmaların keşide yeri olarak yazılması halinde çek bu niteliğini korumalı, buna karşın ne anlama geldiği bilinmeyen kisaltmaların yazllması halinde keşide yeri gösterilmemiş sayılmalıdır. Bu konudaki ölçü keşidecinin irade beyanının hiçbir kuşkuya yer vermeyecek şekilde anlaşılabilir olup olmamasıdır... Medeni Kanunun 2.maddesindeki iyi niyet kuralı ve hukuk güvenliği de çeklerde keşide yerinin kısaltılmış olarak yazılmasına olumlu bakılmasını gerektirmektedir. Öğreti de keşide yerinin aynen yazılması konusunda katı bir görüş yoktur...Bu itibarla çeklerde keşide yerinin hiçbir duraksamaya meydan vermeyecek şekilde anlaşılabilir olması koşulu ile kısaltılmış olarak yazılması halinde sadece bu nedenle çekin geçersiz sayllamayacă̆ doğrultusunda içtihatların birleştirilmesine karar verilmelidir." Buradan hareketle çekler açısından düzenleme yerinin kısaltılarak yazılması halinde bu ifadenin hiçbir yeri işaret etmiyor olması veyahut birden çok yeri akla getirmesi halinde düzenleme yerinin geçersizliği sonuca varılmalıdır ${ }^{140}$.

\footnotetext{
${ }^{139}$ RG, 06.05.1993, S:573, s. 41-51.

${ }^{140}$ Moroğlu, s. 516.
}

190 Ankara Hacı Bayram Veli Üniversitesi Hukuk Fakültesi Dergisi C. XXV, Y. 2021, Sa. 2 
Öncelikle bu verilen kararda dikkatimizi çeken ilk husus, Yargıtay'ın Ceza Daireleri arasındaki içtihat farklılı̆̆ın giderilmesi olup, buradaki aykırılı̆̆ın keşide yerinin kısaltılmış olarak yazılmasının çekin kambiyo senedi vasfını ortadan kaldırıp kaldırmayacağı ve çekin sırf bu sebeple geçersiz olup olmayacağı noktasında toplanmaktadır. Oysaki çözümlenmesi gereken hukuki mesele bundan da öte olan buradaki kısaltmanın ne şekilde geçerli olduğunun var sayılacağıdır. Yoksa, bu tespit olmadan zaten halihazırda çekin kambiyo senedi olup olmadığı değerlendirmesi yapılamayacaktır. $\mathrm{Bu}$ noktada hangi hukuki sorunun çözümü olduğu noktasında yapılan tespit açısından kararın eleştirileceğinden şüphe edilemez ${ }^{141}$. Çünkü düzenleme yerinin yapılan kısaltmanın belirsiz nitelikte olmasıyla doğrudan ilişkisi vardır. Bunun haricinde her ne kadar doktrinde hemfikir olabilecek şekilde çekler hakkında alınmış bu kararın doğrudan bonoya tatbik edileceği kabul edilmekteyse de ${ }^{142}$ kanaatimiz bu yönde değildir. Kanaatimizi açıklamadan önce konuyla ilgili mevzuatı irdelemek gerekir. Bu bağlamda Yargıtay Kanunu'nun 45. maddesinin 5.fikrası uyarınca; "İçtihadı birleştirme kararları benzer hukuki konularda Yargitay Genel Kurullarını, dairelerini ve adliye mahkemelerini bağlar." Ayrıca söz konusu karar açısından da Yargıtay Kanunu'nun 16. maddesinin 5. bendinden "Hukuk Genel Kurulunun benzer olaylarda birbirine aykırı biçimde verdiği kararları ile Ceza Genel Kurul Kurulunun yine benzer olaylarda birbirine aykirl olarak verdiği kararlart veya Hukuk Genel Kurulu ile Ceza Genel Kurulu; Hukuk Genel Kurulu ile bir hukuk dairesi; Hukuk Genel Kurulu ile bir ceza dairesi veya Ceza Genel Kurulu ile bir ceza dairesi; Ceza Genel Kurulu ile bir hukuk dairesi veya bir hukuk dairesi ile bir ceza dairesi arasındaki içtihat uyuşmazlıklarını gidermek ve içtihatlar birleştirmek" şeklinde ortaya çıkan bir görevin Yargıtay Büyük Genel Kurulu'na verildiğini görmekteyiz. Bu hükümler birlikte değerlendirildiğinde uyuşmazlığın benzer hukuki sorunlar olması gerektiği ve ancak bu şekilde daireler arasındaki ayrılığın içtihatların birleştirilmesi yoluyla giderilebileceği kabul edilebilir. O halde benzer hukuki sorunlar, yani benzer olaylardan kasıt çek açısından düzenleme yerinin kısaltılarak yazılması esnasında ortaya çıkabilecek varyasyonlardır; yoksa bono veyahut poliçedeki

${ }^{141}$ Sorunun hukuki olmayıp olgu sonucunda inançların birleştirilmesi söz konusu olamayacağ yönündeki karşı oy yazısı için bkz. Çetin Aşçığlu, s. 51.

${ }^{142}$ Moroğlu, s. 517; Poroy/Tekinalp, N. 417, s.246; Kendigelen/Kırca, s. 177; Ülgen/Helvac1/ Kaya/Nomer Ertan, s. 146; Bozer/Göle, dipnot 90, s. 210; Pulaşl1, s. 242; Kayar, s. 130. Kamu tarafından bilinen ve hataya sebebiyet vermeyen kısaltmaların kabul gördügü yönünde bkz. Kınacıoğlu, s. 113. 
düzenleme yeri açısından bir kıyas yapılmasının içtihatların birleştirilmesi kararı açısından doğru bir yöntem olduğunu düşünmemekteyiz. Aksi halde istisnai olan bağlayıcı mahkeme kararının kural halini almasına sebebiyet verilir ki; bu hukuki güvenlik ilkesini zedeler niteliktedir. Ayrıca düzenleme yerinin yokluğu çek açısından diğer unsurların bulunması kaydıyla adi havale hükmünde iken; bonoda soyut borç ikrarı olacaktır. Bu bile bize çek ile bono arasında bir benzerliğin kurulamayacağını göstermektedir. Pek tabidir ki, bu konuda çekin işleyişi ile bononun piyasadaki tedavül sürecinin de farklılığ vb. şeklinde birçok ayırıcı argüman bu benzerliğin kurulamayacağını bize gösterebilir. $\mathrm{O}$ halde bonolar açısından açık bir şekilde düzenleme yerinin kısaltılarak yazılıp yazılamayacağı konusunda bir içtihadı birleştirme kararı verilinceye kadar düzenleme yerinin kısaltılması bakımından bir kriterin benimsenmesini gerektirir. Bu yüzden öncelikle içtihadı birleştirme kararındaki hiçbir duraksamaya yer vermeyecek şekilde anlaşılabilir olması kıstasının Öztan'ın da dile getirdiği üzere ${ }^{143}$ her somut olay örgüsü içerisinde -senet harici unsurlardan hareketle bir sonuç çıkarılamaması esasında olduğu gibi- bu tarz bir genellemeye gidilmemesi gerekir. Hatta kararın karşı oy yazısındaki bir görüşe göre $\mathrm{de}^{144}$, hangi kısaltmaların hangi anlamlara geleceğini belirleyen listelere yer verilmesi gibi bir durum ortaya çıkacaktır; bu güncel gelişmeler karşısındaki kazuistik metodu çağrıştırmaktadır ve muhakkak reddedilmelidir. Ayrıca hem icra müdürü hem de icra mahkemesi yapılan takiplerde ya da başvurularda bonoda düzenleme yerinin mevcudiyetini re'sen araştıracağından (İ̈K m. 68, 168/1, 170a) ${ }^{145}$ bilhassa ceza hukuku bakımından senedin resmi evrak mı yoksa adi senet mi sayılacağ 1 konusunda içtihadı birleştirme kararının vardığı sonuç kabul edilecek olursa bunun suçta ve cezada kanunilik ilkesini zedeleyebilecek nitelikte olduğundan hareketle ${ }^{146}$ de bu tespite ihtiyatlı yaklaşılmalıdır. Nitekim içtihadı birleştirme kararındaki gerek çekteki düzenleme yerinin tüm harfleri eksiksiz biçimde yazılarak geçerli kabul edilmesi ile gerek çekte düzenleme yerinin duraksamaya yol açmayacak biçimde anlaşılabilir olması yeterli görülmesi hali arasında sonuç itibariyle -kural olarak- bir farklılık yaratmayacağı gerekçesiyle ${ }^{147}$

\footnotetext{
${ }^{143}$ Yabanc1lık unsurunu ihtiva eden senetler bakımından da bu sorun göz önünde tutulmalıdır. Bkz. Fırat Öztan, Kıymetli Evrak Hukuku, 2. Bask1, Turhan Kitabevi, 1997, s. 472.

${ }^{144}$ Sami Selçuk, s. 48.

${ }^{145}$ Uyar, TBB, s. 314; Uyar, s. 3; Öztan, s. 87; Moroğlu, s. 509; Ülgen/Helvac1/Kaya/Nomer Ertan, s. 146.

${ }^{146}$ Benzer yöndeki karşı oy yazısı için bkz. Muharrem Dinç, s. 50.

${ }^{147}$ Benzer yöndeki karşı oy yazısı için bkz. Sami Selçuk, s. 44-45.
} 
yol gösterici nitelikte olsa da ${ }^{148}$ genel geçer nitelikli bir kriter olarak genel anlamda herkes tarafından bilinen ve tek bir yer şeklinde tespit edilen bir yerin kısaltılması halinde bonoda düzenleme yeri olarak geçerli kabul edilmesi yolu tercih edilmelidir.

Öncelikle bonoda düzenleme yerinin belirli olması şartıyla kısaltılarak da yazılabileceği kabul edilmelidir. Zaten düzenleme yerinin tarafların iradesiyle belirlenebilir ve tek olması kaydiyla kısaltılması halinde de geçerli olarak kabulü tartışmasızdır. Bu bağlamda çekin düzenleme yerinin kısaltılması yalnızca genel olarak biliniyor olması halinde geçerlidir; yoksa bu kısaltma Federal Almanya sınırları dahilinde birçok yere işaret ediyorsa -bu kapsamda birden çok büyük şehri akla getiriyorsa- geçersizdir ${ }^{149}$. O halde yapılan kısaltmalarda Ffm için Frankurt am Main, D'dorf için Düsseldorf, K'lautern için Kasierlautern, Recklingh için Recklinghausen anlaşılacağından düzenleme yerinin geçerli olduğu kabul edilir ${ }^{150}$. Bu yüzden düzenleme yeri açık ve anlaşılır bir şekilde gösterilmemesi halinde düzenleme yeri geçersizdir. Misalen $\mathrm{Re}^{151}$ kısaltması bir yer olarak yeterince anlaşılır bir bilgi ihtiva etmemesi dolayısıyla düzenleme yeri olarak kabul edilemez. Çünkü Regensburg, Remscheid gibi anlamlara da gelecek bu ibarenin çok sayıda yere gönderme yaptığı akla gelebiliri ${ }^{152}$. Nitekim bir ile ya da ilçeye bağlı olmayan şehirler bakımından plaka kısaltmalarına dair bilginin Çek Kanunu bağlamında yeterince açık bir yer bilgisini münhasıran büyük harflerin kullanılması halinde taşıyacağı kabul edilir ${ }^{153}$. Bu yüzden Türk hukuku açısından da TDK'ya uygun olarak kırpılarak kısaltılacak yer adları açısından en azından ilk harfin büyük yazılmaması gerekliliği -özel ad olması hasebiyle- kabul edilmelidir. Ayrıca kısaltma kullanıldığı hallerde düzenleme yerinin açıkça anlaşılamaması varsayımında senet metninin yorumlanmasından hareketle düzenleme yeri

${ }^{148}$ Bazı kısaltmaların tereddüde yol açabileceği gerçeği de yadsınamaz. Bkz. Feyzan Hayal Şehirali, "Yargıtay Kararlarında Karşılıksız Çek", 1997, 52(1-4), AÜSBFD, s. 669 <https:// dergipark.org.tr/tr/pub/ausbf/issue/3109/43043> Erişim Tarihi 20.11.2020.

149 OLG Hamm, Urteil vom 14.10.1994- 7 U 104/94, NJW-RR 1995, 112.

${ }^{150}$ Baumbach/Hefermehl, WG Art.1, Rn. 12, s. 115. Oysaki Wilmersdorf yerine Wdf kisaltmasının senedi geçersiz hale getireceği yönünde bkz. KG JW 25, s. 496.

${ }^{151}$ Oysaki RE şeklinde büyük harflerle kısaltılan yer adının geçerli olduğu yönündeki karar için bkz. OLG Hamm, Urteil vom 12.12.1997 - 7 U 89-97, NHW-RR, 1998, 1345.

${ }^{152}$ OLG Hamm NJW-RR 1995, 112, 113.

${ }^{153}$ OLG Hamm NJW-RR 1995, 112. Plakaların küçük harflerle yazılması halinde düzenleme yeri olarak kabul edileceği yönünde bkz. Bülow, WG Art. 1, Rn. 38, s. 24. 
tespit edilmeye çalışılır ${ }^{154}$. Buradan da bir sonuç çıkmazsa senedin geçersizliği gündeme gelir ${ }^{155}$. Mesela Porta Westfalica için yapılan POW kısaltması genel olarak bilinmemektedir. Her ne kadar bir bankaya dayanılarak -Sparkasse Schaumburg- düzenleme yeri belirlenmeye çalışılmışsa da bu yorum yoluyla dahi tespit edilememektedir. Zira gerek internet ortamında yapılan araştırmalar neticesinde nadiren de olsa PoW kisaltmasının Porta Westfalica anlamında kullanılması gerek başkaca kullanımlarla bu kısaltılmanın yapılabilirliği (Porta Westf. Ya da P. Westfalica) düzenleme yerinin geçersizliğine sebebiyet verir $^{156}$. Yapılan bu açıklamalarda Alman hukuku açısından yer adlarının plakalar doğrultusunda şekillendirildiği göz önüne alındığında uygulamanın hangi yönde seyir izlediği noktasında kendiliğinden nasıl bir kriterin kabul edildiği çıkarımında bulunulabilir. Oysaki Türk hukukunda böyle bir uygulama olmadığ1 için bizce 81 vilayeti göz önünde tutarak beş harf ve fazlası için yapılacak kısaltmalarda kural olarak ilk üç sessiz harfin alınması ve birleşik kelimelerin ${ }^{157}$ bu kapsamın dışında tutulması gerektiğini söyleyebiliriz.

Nihai olarak bonoda düzenleme yerinin kısaltılarak yazılabileceğini; ancak bu yazımın TDK kuralları çerçevesinde gerçekleşmesi gerektiğini ve bu kısaltma yapılırken de herkes tarafından ilk görüşte aynı yönde anlaşılması gerekliliğinden bahsedilmelidir ${ }^{158}$. $\mathrm{Bu}$ gereklilik yerine getirilirken gerektiğinde yorum yoluyla senet metnindeki diğer verilerden hareketle de bir sonuca ulaşılabileceği gerçeği de dikkate alınmalıdır. Bu bağlamda İst. ${ }^{159}$, Çukurçayır B1. ${ }^{160}$, Kumbağ 1 Beldesi T.D. ${ }^{161}$ bonoda düzenleme yeri

${ }^{154}$ Bülow, WG Art. 1, Rn. 38, s. 23. Bununla birlikte senet metni dışındaki diğer hususların yorumda dikkate alınmaması gerektiği hususunda bkz. Meier Hayoz/von der Crone, §7, Rn. 39, s. 130 .

${ }^{155}$ OLG Hamm, Urteil vom 12.06.2012 - I-7 U 3/12, BeckRS 2012, 17925.

156 OLG Hamm, BeckRS 2012, 17925; NJW 2013, 395,396.

${ }^{157}$ Çnk kısaltması ile Çanakkale, Çankırı ya da Çankaya kastedilmiş olabilir. Bkz. Poroy/Tekinalp, N. 206, s. 130. Bu yüzden Çanakkale için Ç. Kale; Çankırı için Çnkr; Çankaya için Çnky kısaltması kullanılmalıdır.

${ }^{158} \mathrm{Bu}$ durumu Kınacıŏlu şu şekilde ifade etmiştir: "Keşide yerinin yazılmasında kamuca bilinen ve yanıltmayan kısaltmalar yapılabilir." Bkz. Kınacıoğlu, s. 113. Benzer şekilde Öztan' da bu durumu şu şekilde dile getirmiştir: "Keşide yerinin tıpkı keşide tarihi unsurunda oldu$\breve{g}$ u gibi belli ve mümkün bir yer olması icap eder.” Bkz. Öztan, 1997, s. 472.

159 Y. 12. HD., 31.05.2018, 2018/9648 E., 2018/5675 K., <https://karararama.yargitay.gov.tr/ >Erişim Tarihi 20 Aralık 2020.

160 Y. 12. HD., 14.04.2014, 2014/8940 E., 2014/10754 K., <https://karararama.yargitay.gov.tr/ $>$ Erişim Tarihi 20 Aralık 2020.

161 Y. 12. HD., 19.06.2012, 2012/826 E., 2012/21235 K., <https://karararama.yargitay.gov.tr/

194 Ankara Hacı Bayram Veli Üniversitesi Hukuk Fakültesi Dergisi C. XXV, Y. 2021, Sa. 2 
olarak genel anlamda biliniyor olduğundan hareketle geçerli bir şekilde kararlaştırılabilecekken; Ant. ${ }^{162}$, K. Ören ${ }^{163}$, ESK ${ }^{164}$, S.Bolu ${ }^{165}$, G. Antep, Ş. Urfa, K. Maraş ${ }^{166}$, C.p. mh.H. sk.A Blok D'.13 N:28 Ç.Kale ${ }^{167}$, S. beyli ${ }^{168}$, L. Burgaz ${ }^{169}$ da ise düzenleme yerinin belirsizliğe yol açacağ 1 gerekçesiyle bononun kambiyo senedi vasfinı yitirmesine yol açar.

\section{DÜZENLEME YERİNIN YOKLUĞU, NOKSANLIĞI YA DA GEÇERSIZLIIĞI SONUCUNDA ORTAYA ÇIKAN HUKUKI DURUM}

Bonoda düzenleme yerinin anlamı, sebep ve sonuçlar bağlamında önem arz eder. Yapılacak nitelendirmede düzenleme yerinin ya da alternatif unsurun varlığı/yokluğu maddi ve şekli hukuk bakımından önemli sonuçlara, dolayısıyla farklılıklara sebebiyet verir.

Bonoda düzenleme yerine açıkça verilmemesi, yokluğu halinde alternatif bir yerin de belirtilmemesi ve genel olarak da düzenleme yerinin birden çok ya da belirsizliğe yol açacak şekilde gösterilmesi hallerinden en azından birisinin somut olayda gerçekleştiği durumlarda bononun geçersizliğ $i^{170}$ söz

>Erişim Tarihi 20 Aralık 2020. Bilhassa bu örnekte ilk bakışta tek başına kullanılan yerin belirsizliğe sebebiyet verdiği düşünülecekse de yanındaki ibareyle yorum yoluyla belirlilik sağlanmaktadır.

${ }^{162}$ Y. 12. HD., 26.04.2017, 2016/14087 E., 2017/6541 K., <https://karararama.yargitay.gov.tr/ >Erişim Tarihi 20 Aralık 2020.

163 Y. 12. HD., 15.12.2016, 2016/6351 E., 2016/25469 K., <https://karararama.yargitay.gov.tr/ >Erişim Tarihi 20 Aralık 2020.

${ }^{164}$ Y. 19. HD, 10.02.2016, 2015/15538 E., 2016/2060 K.; Y.12. HD., 22.05.2017, 2007/8344 E., 2007/10563 K., <https://karararama.yargitay.gov.tr/ >Erişim Tarihi 20 Aralık 2020.

${ }^{165}$ Y. 27.04.2015, 12. HD., 2015/3687 E., 2015/11312 K., <https://karararama.yargitay.gov. tr/ > Erişim Tarihi 20 Aralık 2020. Biz bu kararda varılan sonucun doğru olmadığını, bu kısaltmanın doğrudan Safranbolu'ya işaret ettiğini kabul etmeliyiz.

166 Çarşamba/Samsun ibaresinden hareketle verilen bu örnekler için bkz. Y. 12. HD., 04.05.2012, 2011/29563 E., 2012/15122 K., <https://karararama.yargitay.gov.tr/ >Erişim Tarihi 20 Aralık 2020.

167 Y.12. HD., 24.09.2013, 2013/19150 E., 2013/29669 K., <https://karararama.yargitay.gov.tr/ >Erişim Tarihi 20 Aralık 2020.

${ }^{168}$ Y.11.CD., 23.01.2019, 2017/16277 E., 2019/834 K., <https://karararama.yargitay.gov.tr/ >Erişim Tarihi 20 Aralık 2020.

${ }^{169}$ Y. 12. HD., 07.09.2015, 2015/9716 E., 2015/19930 K., <https://karararama.yargitay.gov.tr/ >Erişim Tarihi 20 Aralık 2020.

${ }^{170}$ TBK m. 27/1 bağlamında kanuni şekil şartlarına uyulmaması hali geçersizliğin butlan olarak anlaşılmasını gerektirir. Butlan sebepleri hakkında ayrıntılı bilgi için bkz. Fahri Erdem 
konusu olur ${ }^{171}$. Zira TTK m. 777/4 hükmü uyarınca da düzenlendiği yer gösterilmeyen bir bononun düzenleyenin adının yanında da yazılı bir yerde yoksa bu senet bono sayılmaz (TTK m. 777/1) ${ }^{172}$. Doktrinde ${ }^{173}$ ve Yargitay'in verdiği kararlar ${ }^{174}$ doğrultusunda bu hallerde bononun geçersizliği kabul edilse de, acaba bonodaki taahhüdün geçerli olmasından hiçbir şekilde bahsedilemeyecek midir? ${ }^{175}$

$\mathrm{Bu}$ bağlamda düzenleme yeri sarahaten belirtilmemiş ve kanunen de alternatifine yer verilmeyen bir bono kural olarak soyut borç ikrarı say1lır ${ }^{176}$. Dolayısıyla kambiyo senedi vasfina sahip olmayan bu belge adi senet olarak kabul edilip senedin alacaklısı kambiyo senetlerine ilişkin özel takibe

Kaşak, Sözleşme Özgürlüğünün Sınırı Olarak Kanunun Emredici Hükümlerine Aykırılık, 1. Bas1, Onikilevha Yayıncılık, s. 366-367. Kanuni gerekliliklerin yerine getirilmemesi halinde bono batıldır. Hâkim batıl olan bonoyu re'sen dikkate almalıdır. Hâkimin bu boşluğu doldurma imkânı yoktur (Aynı yönde bkz. Rehfeldt/Zöllner, s. 58; Hueck, § 8, s. 40. Bir ihtirazi kayıtla benzer yönde bkz. Stanzl, s.33). Senet metninden anlaşılan eksiklikler tüm hamillere karşı ileri sürülebilir. Bkz. Meier Hayoz/von der Crone, §7, Rn. 37, s. 129.

${ }^{171}$ Benzer yönde bkz. Rehfeldt/Zöllner, s. 58; Baumbach/Hefermehl, WG Art. 2, Rn. 8, s. 122; BSK Wertpapierrecht- Grüninger/Hunziker/Roth, Art 991 OR, Rn. 22; Schoele, s. 6.

${ }^{172}$ Bonoda düzenleme yerine dair hükmün amaçsal yorumundan hareketle sözleşme özgürlügünden daha üstün bir değeri korumayı hedeflediği ve söz konusu kanun hükmünün kamu düzenini ve hukuki güvenliği koruması sebebiyle emredici nitelikte olduğu sonucuna ulaşılmalıdır. Kanun hükmünün özünden hareketle emredici karakterde olup olmadığını tespiti konusunda bkz. Kaşak, s.314 vd.

${ }^{173}$ Doktrinde düzenleme yeri olmayan bonoların geçersizliğini kabul eden görüşler (adi senedin varlığını ayrıca irdeleyen) için bkz. Arslanlı, s. 68; Domaniç, s. 474; İmregün, s. 52; Tekil, s. 117; Kınacioğlu, s. 117 ve 118; Moroğlu, s. 508; Poroy/Tekinalp, N. 419, s. 285; Öztan, s.87 ve 211; Ülgen/Helvacı/Kaya/Nomer Ertan, s. 145 ve 146; Kendigelen/Kırca, s. 176 ve 178; Bahtiyar, Kıymetli Evrak, s. 122 ve 126; Bozer/Göle, s. 185; Pulaşl1, s. 140; Kayar, s. 129; Eriş, s. 538 ve 540; Uyar, TBB, s. 312; Uyar, s. 33; Börü, s. 147. Çekler açısından bkz. Kendigelen, Çek, s. 116 ve 125. Ayrıca bkz. Bülow, WG Art. 76, Rn.1, s. 349; Wiefels, 49.

${ }^{174}$ Y.19.HD., 10.06.2020, E.2018/3885, K. 2020/928; Y.15.HD., 02.12.2019, E. 2019/951, K. 2019/4947; Y. 12. HD, 18.09.2019, E. 2019/9614, K. 2019/12959; Y. 13. HD., 29.05.2019, E. 2016/11479, K. 2019/6761; Y. 13. HD., 04.03.2019, E. 2016/28981, K. 2019/2844; Y. 12. HD., 22.11.2018, E. 2017/6337, K. 2018/12027; Y.12.HD., 15.11.2018, E. 2017/5738, K. 2018/11596; Y. 13. HD., 22.10.2018, E. 2016/3166, K. 2018/9837; Y. 12.HD., 02.07.2018, E. 2017/5880, K. 2018/7116; Y.12.HD., 20.03.2018, E. 2018/1755, K. 2018/2819; Y.12. HD., 20.03.2018, E. 2016/29762, K. 2018/2821; Y.12.HD., 22.02.2018, E. 2018/850, K. 2018/1873; Y.12.HD., 13.02.2018, E. 2016/27916, K. 2018/1227, <https://karararama. yargitay.gov.tr/ > Erişim Tarihi 20 Aralık 2020.

${ }^{175}$ M. Fadllullah Cerrahoğlu, Türk Ticaret Kanununa ve Yargıtay İçtihatlarına Göre Bonoda Mutlak Defiler, 1. Bası, İstanbul İktisadi ve Ticari İlimler Akademisi, Hüsnü Tabiat Matbaas1, 1974, s. 34 vd.; Özdamar/Göktürk/Can/Kaşak, s.207.

176 Baumbach/Hefermehl, WG Art.2, Rn. 14, s. 125; Moroğlu, s. 508-509. 
başvuramaz ${ }^{177}$. Evvela belirtmek gerekir ki; somut olayda bonoyu düzenleyen kişinin iradesinin ne olduğunun açıklığa kavuşturulması gerekir. Yorum yoluyla ulaşılacak sonuca göre; akla gelebilecek soru şudur: Acaba taraflar (düzenleyen ile senedin hamili) arasındaki anlaşmaya istinaden senet tedavüle çıkarılırken senette belirtilmeyen düzenleme yerinin sonradan tamamlanması $\mathrm{m} 1$ söz konusudur? Bu soruya olumlu cevap verilecek olursa açık bonodan ${ }^{178}$ bahsedilerek TTK m. 778/2-f bendi hükmü uyarınca; TTK m. 680 hükmünün uygulanması gerekir. Şayet bu soruya olumlu cevap verilemezse, senet metninde yapılacak bir tashihten ziyade senet metnindeki tahrifat ${ }^{179}$ gündeme gelebilir. Bu olasılık dahilinde ise doldurma yetkisi anlaşmasının yokluğuna istinaden eksik bononun varlığ kabul edilebilir ${ }^{180}$. Bu cihetle eksik bonoda ${ }^{181}$ noksan unsur olan düzenleme yerinin yetkili olmayan kimse tarafindan doldurulmasına kanunen izin verilmediğinden tahrifattan yani bir nev'i evrakta sahtekarlıktan söz edilmesi gerekir ${ }^{182}$. Pek tabi burada hiçbir surette emre yazılı ödeme vaadi iddiasında bulunulamaz. Çünkü konu açısından emre yazılı ödeme vaadinden söz edilebilmesi için bono kelimesini ihtiva etmeyen; ancak açıkça emre yazılı olarak düzenlenip, bono için kanunda öngörülen asgari unsurları içeren bir senedin varlığı aranır ${ }^{183}$. Oysaki düzenleme yerinin yokluğu senedi emre yazılı ödeme vaadi olmaktan çıkartan bir unsurdur. O

177 Öztan, s. 211; Uyar, s. 38.

${ }^{178}$ Karayalçın, s. 90-91; Tekil, s. 118; Ülgen/Helvac1/Kaya/Nomer Ertan, s. 156 vd.; Bozer/ Göle, s. 214 vd.; Pulaşlı, s. 150. Açık bononun tahvili mümkün değildir. Bkz. Öztan, s. 88. Ayrica bkz. Hueck, § 8, s. 40; Meier Hayoz/von der Crone, §7, Rn. 41 ff., 130 vd.; Baumbach/Hefermehl, WG Art. 2, Rn. 13, s. 124-125; BSK Wertpapierrecht- Grüninger/Hunziker/Roth, Art 991 OR, Rn. 25; Stanzl, s. 33-34.

179 Öztan, s. 88. Yargıtay'ın vermiş olduğu bir karar uyarınca; senet fotokopisinde düzenleme yerinin yazılı olmamasına rağmen, icra kasasındaki senet aslında bunun belirtilmiș olması halinde, senedin bono niteliğini taşıyacağını belirtmişse de Uyar da bu karar katılmamaktadir. Bkz. Uyar, TBB, s. 313. Biz de bu karara katılmamakla beraber burada senette yapılan bir tahrifattan bahsedilmesi gerektiğini, düzenlenme iradesinin vuku bulduğu anda düzenleme yerinin kural olarak yazılması gerektiği kabul edilmelidir.

${ }^{180}$ Poroy/Tekinalp, N. 220, s. 161.

${ }^{181}$ Açık bono ile eksik bono farklı kavramlar olduğu ve eksik bonoda tarafların arasında mevcut boşlukların nasıl doldurulması gerektiği hususunda bir anlaşmanın söz konusu olmadığı iddiası lehtar gibi son hamile karşı da ileri sürülebilecektir. Bkz. Bozer/Göle, s. 216.

182 Öztan, s. 90; Hueck, § 8, s. 40-41. Eksik bilgilerin sonradan tamamlanmasının sahtekarlık anlamına geldiği hususunda bkz. Meier Hayoz/von der Crone, §7, Rn. 39, s. 130. Aynı yönde bkz. Rehfeldt/Zöllner, s. 58.

183 Poroy/Tekinalp, N. 422, s. 288; Ülgen/Helvac1/Kaya/Nomer Ertan, s. 151; Özdamar/Göktürk/Can/Kaşak, s. 208. Emre yazılı ödeme vaadlerini, bonoya ilişkin birtakım özelliklere sahip olmadıkları gerekçesiyle eksik bono saymak gerektiği yönünde bkz. Öztan, s. 211. 
halde mezkûr soruda -düzenleme yerinin yokluğu açısından- bonoda kanuni tahvile örnek teşkil eden TTK m. 830 hükmü ${ }^{184}$ uygulanamaz mahiyettedir. Bu takdirde bono açısından iradi tahvil müessesesinin uygulanıp uygulanmayacağ 1 tartışılmalıdır. Zira daha önce de belirttiğimiz üzere düzenleme yerine hiçbir surette yer verilmemiş bono açısından yapılacak hukuki nitelendirmede soyut borç ikrarı bağlamında yalnızca bir kural söz konusudur. Bu kuralın istisnasına -her ne kadar Türk hukukunda BGB § 140'ta olduğu üzere ${ }^{185}$ tahvile açıkça yer verilmemiş ise de $^{186}$ - bononun düzenlenmesi esnasında tahvilin şartlarının gerçekleşip gerçekleşmediğinin her defasında incelenmesi suretiyle ulaşılabilirr ${ }^{187}$. O halde tahvil için şu şartların sırasıyla kümülatif

${ }^{184}$ Cerrahoğlu, s. 35.

${ }^{185}$ Bülow, WG Art. 2, Rn. 7, s. 34; Baumbach/Hefermehl, WG Art.2, Rn. 9, s. 122-123.

${ }^{186} \mathrm{Bu}$ konu hakkında ayrıntılı bilgi için bkz. Necip Kocayusufpaşaoğlu/ Hüseyin Hatemi/Rona Serozan/Abdülkadir Arpacı, Borçlar Hukuku Genel Bölüm, 5. Basıdan Tıpkı 6. Baskı, Birinci Cilt, Filiz Kitabevi, 2014, § 44, N. 26 vd., s. 609 vd.; Cerrahoğlu, s. 35 vd.; Karl, s. 52.

${ }^{187}$ Bononun geçersizliği irade açıklamasının hiçbir hüküm ve sonuç doğurmayacağı anlamına gelmeyeceği yönünde bkz. Meier Hayoz/von der Crone, §7, Rn. 38, s. 129; Baumbach/ Hefermehl, WG Art.1, Rn. 12, s. 115; BSK Wertpapierrecht- Grüninger/Hunziker/Roth, Art 991 OR, Rn. 25a. "Taraflar poliçe ve bono düzenlerlerken, geçerli olarak havale veya adi senet düzenliyebilecek iken, yanılglya düşüp hükümsüz poliçe ve bono düzenlememişlerdir. Taraflar pekâlâ geçerli poliçe veya bono düzenliyebilirlerdi ve aralarındaki gerçek amaç da havale veya adi senet düzenlemek değil, poliçe veya bono düzenlemektir. Bu gerçekleşmediğine, tarafların amacı da havale yapmak veya adi senet düzenlemek değil, poliçe ve bono düzenlemek olduğuna göre, zorunlu huşulart içermiyen ve poliçe veya bono olarak sayılamayacaklart yasada belirlenen belgeleri, olsa olsa taraflar arası ilişkilerde 'yazılı kanıt başlangıcı olarak kabul etmek gerekir." Bkz. İmregün, s. 54. Bu görüş tahvil için öngördüğümüz şartlardan (6)'nın hiçbir şekilde gerçekleşmeyeceğinden hareket ederek adi senet olasılığını dahi reddetmektedir. Oysaki tahvil olasılığını göz önünde tutarak -ki geçersiz sayılan bono imzası inkar edilmedikçe sebebi gösterilmeyen borç tanıması olarak ayakta tutulabileceği yönünde bkz. Karlı, s . 52- adi senedin varlığını sorgulayan görüşler için bkz. Arslanlı, s. 68; Karayalçın, s. 90-91; Tekil, s.116-117; Öztan, s. 88; Kınacıŏlu, s. 117. Tahvil tartışmasına girmeksizin düzenleme yeri olmayan bononun adi senet olduğu yönünde bkz. Domaniç, s. 474; Ülgen/Helvac1/Kaya/Nomer Ertan, s. 151; Bozer/Göle, s. 185 ve 209-210; Uyar, TBB, s. 312; Uyar, s. 34; Reisoğlu, s. 69. Şekil şartlarındaki eksiklik dolayısıyla bono olarak geçersiz olan senedi adi senet sayabilmek için tarafların bu konuda geçersizliği bilmeleri halinde dahi adi senet yapacaklardı sonucuna varabilmek gerektiği yönünde bkz. Cerrahoğlu, s. 36. Herhangi bir tahvil tartışması yapmaksızın düzenleme yeri olmayan bono adi senet sayılacaktır. Bkz. Y.13.HD., 18.06.2020, E.2020/6, K. 2020/4926; Y.13.HD., 10.12.2019, E. 2017/2865, K. 2019/12307; YHGK, 27.04.2016, E. 2014/1075, K. 2016/557; -adi yazilı belge- Y. 13. HD, 30.09.2019, E. 2016/21633, K. 2019/9120; -adi belge- Y. 19.HD., 07.03.2016, E. 2015/12666, K. 2016/4048, <https://karararama.yargitay. gov.tr/ > Erişim Tarihi 20 Aralık 2020. Ayrıca tahvil açısından BGB § 780'e göre soyut borç vaadinden ya da tacir düzenleyen ise HGB $§ 363$ Abs.1 S.2 hükmüne göre ticari taahhütten (käufmännische Verfplichtungsschein) bahsedilebilir. Bu son durumda geçersiz bono emre kaydını ihtiva ediyorsa yalnızca emre yazılı senedin varlığı iddiasında bulunulabilir. Emre kaydındaki eksiklik durumunda senet metninde emre yazılı senedin meydana getirilmesinde 
olarak aranması gerekirir8: (1) Tahvil için kesin hükümsüz bir işlem olmalıdır -ki bonoda düzenleme yeri hem asli olarak hem de alternatif şekilde yok ise TBK m. 27/1 hükmü ile TTK m.1530/1 hükmü uyarınca, (2) Bononun geçersiz olduğu düzenleyen ile hamil tarafından bilinmemelidir -ki bu takdirde tacirler arasındaki hususlar haricinde ilke olarak taraflardan yalnızca birisinin hükümsüzlüğü bilmesi tahvile engel teşkil etmez-, (3) Tahvil hükümsüzlüğü öngören normun anlam ve amacına ters düşmemelidir - teminat, kredi, ödeme işlevlerinden birine veyahut işlem güvenliğine aykırılık yoksa, yedek işlemin geçerlilik şartları oluşmalıdır - (4) Adi senet olarak nitelendirilebilmesi için senet metninin belgelendirdiği hukuki işlem hakkında tam bir bilgiyi ihtiva etmesi ve senedin altının senet aleyhine delil teşkil edecek düzenleyen tarafindan el yazısıyla imzalanması gerekir ${ }^{189}$-, (5) Yedek işlem kesin hükümsüz işlem ile aynı veya benzer sonuçlar doğuran; ancak ondan daha ileriye gitmeyen bir nitelik taşımalıdır- zaten adi senet ile kambiyo senedi ile ulaşılmak istenilen amaç kısmen de olsa karşılanacaktır-, (6) Tarafların yaptıkları işlemin geçersiz olduğunu bilselerdi yedek işlemi istemiş olacakları söylenebilmelidir -hatır bonolarıyla ilgili duruma istisna tanıyarak olayın hal ve şartlarına göre, taraflar yaptıkları işlemin hükümsüz olduğunun farkına varmış olsalardı, tamamen aynı sonuçları doğurmamasına rağmen, yedek işlemin, yani adi senedin sağladığ 1 sonuçlarla yetinmeyi kabul ederlerdi diye düşünmek mümkün olabiliyorsa ${ }^{190}$, bu şart gerçekleşmiş sayılacaktır-

O halde tahvil için aranan şartlardan her birinin somut olayda ayrı ayrı gerçekleşmesi halinde düzenleme yerini bir şekilde ihtiva etmeyen bono soyut borç ikrarına havi bir adi senet olarak karşımıza çıkar. Ancak (2) şart bakımından tacirlerin ticaretine ait tüm faaliyetlerinde basiretli iş adamı gibi hareket etme yükümlülüğü söz konusu olduğundan düzenleme yerine dair bilgisizliğin bu konuda hukuki bir telafisi olamaz. Bu yüzden bononun taraflarının tacir olması halinde tahvilin şartları gerçekleşmeyeceğinden soyut borç ikrarından

düzenleyenin iradesinden yola çıkıldığında tahvile başvurulamaz. Bülow, WG Art. 76, Rn.1, s 350; Stanzl, s. 34; Baumbach/Hefermehl, WG Art.1, Rn. 14, s. 125. Bu yöndeki tartışmalar için ayrıca bkz. Hueck, § 8, s. 40; BSK Wertpapierrecht- Grüninger/Hunziker/Roth, Art 992 OR, Rn. 4. Kambiyo senedi benzeri ödeme vaadi olasılığı açısından bkz. Meier Hayoz/von der Crone, §7, Rn. 38, s. 130. Borç vaadi olduğu yönünde bkz. Rehfeldt/Zöllner, s. 58.

${ }^{188}$ Kocayusufpaşaoğlu, § 44, N. 31 vd., s. 614 vd.

189 Yazılı belgede borçlunun imzası yok ya da imzası sahte ise, bu belge senet sayılmaz. Bkz. Baki Kuru, İstinaf Sistemine Göre Yazılmış Medeni Usul Hukuku Ders Kitabı, 1. Bası, Yetkin Yayıncılık, 2017 s. 254.

${ }^{190}$ Cerrahoğlu, s. 36. 
bahsedilemeyecekse de, adi senedin şartları varsa somut olayda en azından adi senedin varlı̆̆ kabul edilebilir. Bunun dışında (6) şart bakımından hatır bonolarında alacaklının menfaatine düzenlenen tedavül gayesi olanların ${ }^{191}$ artık en azından adi senet olarak geçerli sayamayacağımızdan düzenleme yeri olmayan bononun geçersizliği daimidir ${ }^{192}$. Zira tedavül gayesi ortadan kalktığından hatır bonosunu tedavül kabiliyetine sahip olmayan bir senedi bono olarak dahi ayakta tutamayı $\mathrm{z}^{193}$. Oysaki tedavül gayesi olmayan hatır bonolarında $^{194}$ ise tahvilin işletilebileceği; çünkü (5) şartın (6) ile birlikte sağlandığı kabul edilebilir. Zaten hatır senetlerinde diğer bedelsiz senetlerden farklı olarak ciddi borç altına girme iradesinin olmaması yönünde taraflar anlaşmışlardır ${ }^{195}$.

Soyut borç ikrarı ile adi senet kavramlarının örtüştüğü noktalar olsa da aynı anlama gelmediklerini söylemeliyiz. Bu bağlamda düzenleme yerinin yokluğu, noksanlığ 1 ya da geçersizliği söz konusu olduğunda soyut borç ikrarının ${ }^{196}$ hukuki niteliği açısından kabul ettiğimiz görüşe göre ${ }^{197}$; TBK m. 18 'deki ifadeden söz konusu ikrara hangi sonuçların bağlanması gerektiği belirtilmediğinden taraflar sözleşme serbestisi gereğince; ya yalnızca ispat soyutluğu ile yetinebilir ya da kurucu bir borç vaadi düzenleyebilir. O halde bonodaki düzenleme yerinin olmaması halinde ${ }^{198}$ tarafların o hukuki işlemin

${ }^{191}$ Nurkut İnan, Türk Hukukunda Hatır Senetleri Ve Özellikle Hatır Bonoları, 1. Bası, Bilgi Basımevi, 1969, s. 50-51.

${ }^{192}$ Benzer yöndeki görüş için bkz. Cerrahoğlu, s. 37. Oysaki mevcut bir borç ilişkisinden doğan bir alacak için düzenlenen bononun hükümsüzlüğü bildikleri takdirde tarafların adi senet düzenleme konusunda tereddütte bulunmayacakları yönünde bkz. Cerrahoğlu, s. 36-37. Hatta inançlı işlemler geçerli olduklarından soyutluk ilkesine gidilmesine gerek olmaksızın tedavül gayeli hatır senetleri bu şekilde geçerli kabul edilebilir. Bkz. İnan, s. 116.

${ }^{193}$ Benzer yöndeki görüş için bkz. Cerrahoğlu, s. 37.

${ }^{194}$ Hatır senetlerinde temel alacak farazi olarak dahi yoktur. Bkz. İnan, s. 55. Bununla birlikte tedavül gayesi olmayan hatır senetlerinin hem muvazaalı hem de soyutluğa rağmen muvazaa sebebiyle hükümsüz oldukları sonuca varılabilse de, muvazaalı olsun ya da olmasın hükümsüzlügüu iyi niyetli üçüncü kişilere karşı ileri sürülemez. Bkz. İnan, s. 118.

195 İnan, s. 56.

196 TBK m.18; "Borcun sebebini içermemiş olsa bile borç tanıması geçerlidir."

${ }^{197}$ Kocayusufpaşaoğlu, $\S 11$, N. 47 vd., s. 121 vd. Türk hukukunda esas olarak sözleşme teorisini benimsenmekle beraber tek taraflı irade beyanı teorisinin izlerine de rastlandığı yönünde bkz. Karlı, s. 39.

${ }^{198}$ Oysaki Karayalçın'a göre; emre muharrer senet nitelikli soyut borç senedi olduğu için zorunlu şartların yokluğu halinde ilgililerin o işlemi istemiş olacaklarını kabul etmek; yani mücerret borç senedi lehine bir karinenin varlığından söz etmek gerekir. Bkz. Karayalçın, s. 90-91. Bu bağlamda yazara göre tahvilde belirttiğimiz (6) şartın gerçekleştiğine dair bir 
varlığına işaret etmesi sağlayacak şekilde ispat soyutluğundan istifade etmeleri lehine bir adi karineden bahsedilirr ${ }^{199}$. Zira her iki seçimlik yetki bakımından bütün soyut borç ikrarlarında ispat soyutluğu vardır ${ }^{200}$. Ayrıca tarafların bu ikrara ispat yükünün yer değiştirmesinin ${ }^{201}$ ötesinde bir hukuki sonuç bağlamak istedikleri ${ }^{202}$-kurucu bir borç ikrarı- iddias1 adi karineyi çürüterek ispatlanabilir. Mezkûr adi karineden hareketle somut olayda bonoda düzenleme yeri bir şekilde yoksa şartları varsa adi senetten; o da yoksa senedin geçersizliğinden bahsedilir. Bununla birlikte hukuki sebebi ispat külfetinden kurtulan alacaklının aleyhine bu adi karine çürütülebilirse de soyut borç ikrarına havi bir adi senetten bahsedilecek ve buna göre bir işlem yapılacak demektir.

Delil başlangıcı, iddia konusu hukuki işlemin tamamen ispatına yeterli olmamakla birlikte, söz konusu hukuki işlemi muhtemel gösteren ve kendisine karşı ileri sürülen kimse veya temsilcisi tarafından verilmiş veya gönderilmiş belgedir (HMK m. 202/2). O halde düzenleme yerinin ihtiva etmeyen

karinenin varlığı kabul edilecek olursa soyut borç ikrarının adi senetten bir fark1 kalmayaca$\breve{g} 1$ gibi temel ilişkiye bağlanan kambiyo senedinin de kural olarak her defasında geçersizliğ gündeme gelecektir. Nitekim yazarın görüşünün açıkça aksi kararlaştırılmadıkça mevcut bir borç için soyut borç senedi verildiği zaman bunun ifa amacı ile verilmiş sayılacağı mant1ğından (Kocayusufpaşaoğlu, § 11, N. 49, s. 123; Karlı, s. 110) ileri geldiğini düşünmekteyiz. Oysaki bir kere alacaklı soyut alacağını elde edince temel ilişkiden doğan alacağın sona ermesinden hareketle bononun geçerliliğini etkileyebilecek yasak bir kaydın varlığı şüphesi hasıl olabilir. Zira bonoyu asıl borç ilişkisine bağlayan kayıtlar bononun geçersizliğine yol açar. Ancak bononun hangi amaçla düzenlendiğinin bizzat bono üzerinde gösterilmesi bir sorun teşkil etmez. Diğer bir deyişle yalnızca borcun sebebine, bononun düzenlenme gerekçesine yer verilmesi senedi geçersizliğine yol açmaz. Bu konuda bkz. Kendigelen/Kırca, s. 195. Gerçekten de bu durum soyut borç ikrarı ile adi senet arasında farka işaret etmektedir. Bu farklılık ayrıca kıymetli evrakta hâkim olan hukuki görünüş teorisiyle tamamlanmış sözleşme teorisinin de bir sonucudur. Ayrıca TBK m. 605/1 hükmü uyarınca; "Kumar oynayan veya bahse giren kişi tarafindan imzalanmış adi borç veya kambiyo senedi üçüncü bir kişiye devredilmiş olsa bile, hiçbir kimse bunlara dayanarak dava açamaz ve takip yapamaz. Kıymetli evrakın iyiniyetli üçüncü kişilere sağladiğı haklar saklıdır." Buna göre, kumar ve bahis borçları için düzenlenen soyut borç ikrarlarının soyutluk kuralı rafa kaldırılmıştır (Kocayusufpaşaoğlu, § 11, N.55, s. 128) Bu hükmün istisnai olduğu kabul edilmelidir. Bu yüzden Karayalçın'ın ilgili karine görüşü kabul edilecek olursa soyut borç ikrarı sonucu temel borç ilişkisinden tamamen bağımsız yeni bir borç doğduğu görüşü uygulanamaz hale gelecektir.

${ }^{199}$ Söz konusu kararın bu şekilde anlaşılması gerektiği düşüncesindeyiz. Düzenleme yerine sahip olmayan bononun borç ikrarını içeren adi senet hükmünde olduğu ve ispat külfetinin davalıda olduğu yönünde bkz. Y. 13. HD., 16.02.2016, E. 2015/3196, K. 2016/6282, <https:// karararama.yargitay.gov.tr/ >Erişim Tarihi 20 Aralık 2020.

${ }^{200}$ Kocayusufpaşaoğlu, § 11, N. 53, s. 126; Karlı, s. 82.

${ }^{201}$ Karl1, s. 74.

${ }^{202}$ Kocayusufpaşaoğlu, § 11, N. 53, s. 126. 
bonoların (yazılı) delil başlangıcının maddi unsurunu oluşturabileceği kabul edilebilir ${ }^{203}$. Oysaki Yargıtay kararlarından zamanaşımına uğramış bonoların (yazılı) delil başlangıcı olduğu sonucuna ulaşılmaktadır ${ }^{204}$. Düzenleme yeri yokluğu halinde de şayet iddia konusu hukuki işlemi muhtemelen gösteren yazılı bir belgenin kendisine karşı ileri sürülen kişi ya da temsilcisi tarafından verilmişse ya da gönderilmişse ${ }^{205}$ bono başkaca bir hukuki işlem özellikle de temel borç ilişkisi açısından (yazılı) delil başlangıcı addedilebilir206 ${ }^{206}$.

Yargıtay İçtihadı Birleştirme Kurulu'nun 14.12.1992 tarih ve 1/5 ve Ceza Genel Kurulu'nun 24.03.1998 gün ve 51/106 sayılı kararlarında açıklandığ1 üzere; kambiyo senetlerinde yapılan sahteciliğin resmî belgede yapılmış sayılabilmesi için $^{207}$, ilgili kambiyo senedinin Türk Ticaret Kanunu'nda öngörülen bütün unsurları taşıması gerekir. Bonoda düzenleme yerinin herhangi bir sebeple bulunmaması ceza hukuku açısından bononun özel belge olarak kabul edilmesini gerektirir ${ }^{208}$. Bu takdirde bir özel belgeyi sahte olarak düzenleyen veya gerçek bir özel belgeyi başkalarını aldatacak şekilde değiştiren ve kullanan kişi, TCK m. 207/1209 hükmü uyarınca; özel belgede

${ }^{203}$ Hatta çekte mücerret borç ikrarı olmadı $\breve{g}$ için bonodan farklı olarak bu belgenin (yazılı) delil başlangıcının maddi unsuru niteliği tanınsa dahi inandırıcılığına şüphe ile yaklaşılacaktır. Bkz. Haluk Konuralp, Medeni Usul Hukukunda Yazılı Delil Başlangıcı, Yetkin Yayınları, T1pk1 Basım, 2009, s. 66.

${ }^{204}$ Eriş, s. 583-584. Y.13.HD., 18.06.2020, E.2018/1461, K. 2020/4901; Y.19.HD., 01.06.2020, E. 2018/3795, K. 2020/713; Y.13.HD., 10.03.2020, E.2020/111, K. 2020/3119; Y.23.HD., 04.03.2020, E. 2017/142, K. 2020/1470, <https://karararama.yargitay.gov.tr/ >Erişim Tarihi 20 Aralık 2020. Nitekim Hukuk Genel Kurulu'nun 04.04.2007 gün ve 2007/18-153 E-2007/183 sayılı kararında da benimsendiği gibi "Zamanaşımına uğrayan ve imzası inkâr edilmeyen bono, temel borç ilişkisi bakımından (yazılı) delil başlangıç niteliğindedir.” $\mathrm{Bu}$ konu hakkında ayrıntılı açılamalar için bkz. Konuralp, s. 67 vd.

205 (Yazılı) delil başlangıcının şartları için bkz. Kuru, s. 268.

206 Benzer yöndeki görüş için bkz. Kuru, s. 268. Bu bağlamda bonodaki zorunlu unsurları bulunmaması halinde eksik unsurlu bononun temel alacak bakımından adi bir senet sayılabilecekse de (yazılı) delil başlangıcı olabileceği ihtimali de göz ardı edilmemelidir. Bkz. Konuralp, s. 66. Bu olasılığın düşünülmesi gerektiği hususunda bkz. Ülgen/Helvac1/Kaya/ Nomer Ertan, s. 152.

${ }^{207}$ TCK m. 204/1; “Bir resmî belgeyi sahte olarak düzenleyen, gerçek bir resmî belgeyi başkalarını aldatacak şekilde değiş̧iren veya sahte resmî belgeyi kullanan kişi, iki yıldan beş yıla kadar hapis cezast ile cezalandırllır."

${ }^{208}$ Hasan Tahsin Gökcan, “Özel Belgede Sahtecilik (TCK M.207), 2010, 68(2010/1), Ankara Barosu Dergisi, s. 220 ve $222<$ https://dergipark.org.tr/tr/pub/abd/issue/33777/374082> Erişim Tarihi 20.10.2020.

209 “Bir özel belgeyi sahte olarak düzenleyen veya gerçek bir özel belgeyi başkalarını aldatacak şekilde değiştiren ve kullanan kişi, bir yıldan ü̧̧ yıla kadar hapis cezası ile cezalandırılır." 
sahtecilik suçuna vücut verecektir. Zira TCK m. 201/1 hükmü uyarınca; özel belgede sahtecilik suçunun konusunun, emre veya hamile yazılı kambiyo senedi, emtiayı temsil eden belge, hisse senedi, tahvil veya vasiyetname olması halinde, resmî belgede sahtecilik suçuna ilişkin hükümler uygulanır. Bununla birlikte özel belgenin suça konu olabilmesi için doğrudan hukuki sonuç doğurması gerekir ${ }^{210}$. Bu yüzden bonoda düzenleme yeri herhangi bir şekilde olmadığ 1 takdirde özel belgede sahtecilik suçunun oluşabilmesi için an azından bu belgenin soyut borç ikrarı veyahut hiç olmazsa adi yazılı senet olması gerektiği kanaatindeyiz. Nitekim özel belgenin hukuken korunan bir içeriği ile doğrudan hukuki sonuç doğuran bir irade beyanının ya da bir hususu yansıtması şeklinde anlaşılmas1 ${ }^{211}$ da bunu gerektirir. Bu cihetle, Yargıtay kararlarında bilhassa bu düşüncenin izinden gidilerek bir sonuca varılması gerekir. Ancak Yargıtay'ın böyle bir araştırma yapmaksızın doğrudan bonoda düzenleme yerinin eksikliğine istinaden bonoda sahtecilik yapılması halinde, fiilin özel belgede sahtecilik suçunu oluşturacağını kabul etmektedir ${ }^{212}$.

Son olarak şunu da belirtmekte fayda vardır ki; Yargıtay'ın düzenleme yeri olmayan bononun kural olarak soyut borç ikrarı olmasından değil; adi havale niteliğinden bahsederek birçok hükmü bu şekilde kurduğuna ${ }^{213}$ tanık olmaktayız. Ancak hukuki niteliği itibariyle kararlardan varılan bu yöndeki nitelendirmelerin şartları varsa ancak poliçe ve çek için geçerli olabileceğ $\mathrm{i}^{214}$ söylenmelidir.

\footnotetext{
${ }^{210}$ Gökcan, s. 221.

${ }^{211}$ Gökcan, s. 221.

${ }^{212}$ Düzenleme yeri olmayan bononun özel belge niteliği taşıdı̆̆1 yönünde bkz. Y.11. CD.,14.09.2020, E. 2018/7035, K. 2020/4424; Y.15.CD., 02.07.2020, E. 2020/3967, K. 2020/7290; Y.11.CD., 03.02.2020, E. 2017/14477, K. 2020/756; Y.11.CD., 16.12.2019, E. 2017/16964, K. 2019/9496; Y.11.CD., 02.12.2019, E. 2017/14044, K. 2019/8617; Y. 15 CD., 30.09.2019, E. 2017/14701, K. 2019/9162; Y. 11.CD., 25.09.2019, E. 2017/12369, K. 2019/6703; Y.11.CD., 16.09.2019, E. 2019/1781, K. 2019/6297; YCGK, 21.05.2019, E. 2018/171, K. 2019/453; YCGK, 05.02.2019, E. 2017/527, K. 2019/69, <https://karararama. yargitay.gov.tr/ > Erişim Tarihi 20 Aralık 2020. Ayrıca bkz. Gökcan, dipnot 59, s. 222.

${ }^{213}$ Y. 12. HD., 07.06.2012, E. 2012/28673, K. 2013/5263; Y. 12. HD., 21.02.2013, E. 2013/20060, K. 2013/27679; Y. 12. HD., 10.09.2013, E.2013/34573, K. 2014/45; Y.12. HD., 20.01.2014, E. 2014/6090, K. 2014/9054; Y.12.HD., 12.12.2013, E. 2014/16505, K. 2014/18215; Y.12.HD., 12.01.2016, E. 2015/22265, K. 2016/395; Y.12. HD., 07.02.2017, E. 2016/10094, K. 2017/1393; Y.12.HD., 29.11.2018, E. 2017/8073, K. 2018/12492, <https:// karararama.yargitay.gov.tr/ >Erişim Tarihi 20 Aralık 2020.

${ }^{214}$ Benzer yönde bkz. Moroğlu, s. 508.
} 


\section{SONUÇ}

Bono mevsuf (nitelikli) bir soyut borç ikrarıdır. Bonoda düzenleme yeri alternatif zorunlu bir şekil şartıdır. Bonoda düzenleme yerinin genel olarak ne şekilde gösterileceğine dair herhangi bir bilgiye Kanun'da yer verilmemiştir. Nitekim düzenlendiği yer gösterilmeyen bir bono, düzenleyenin adının yanında yazılı olan yerde düzenlenmiş sayılır. Açıklık bulunmadığı takdirde senedin düzenlendiği yer, ödeme yeri ve aynı zamanda düzenleyenin yerleşim yeri sayılır.

Bonoda düzenleme yeri devletler özel hukuku, medeni usul ve icra iflas hukuku ile ceza hukuku bakımından önemli hukuki sonuçlar doğurmaktadır. Bonoda düzenleme yeri açık, anlaşılır ve okunaklı olması kaydıyla herhangi bir şekilde senetteki taahhüdü ihtiva eden imza ile bağlantı kurularak senedin herhangi bir yerinde belirtilebilir.

Bonoda düzenleme yerinin yabancı bir dilde yazılabileceğini; ancak 805 sayı1ı İktisadi Müesseselerde Mecburi Türkçe Kullanılması Hakkında Kanun'un kapsamının çizilmesi suretiyle kabul edebiliriz.

Düzenleyicisi tek olan bonoda birden fazla düzenleme yeri gösterilirse, bono geçersiz olur. Bununla birlikte bononun birden fazla düzenleyicisi varsa birden fazla düzenleme yerinin tayin edilmiş olmasının bononun geçersizliğine yol açmayacağı doktrinde ifade ediliyorsa da, bu duruma birtakım istisnaların getirilmesi gerekir.

Bonoda düzenleme yerinin kısaltılarak yazılabileceğini; ancak YİBGK'nın çek için hiçbir duraksamaya yer vermeyecek şekilde öngördüğü kıstasın bono için kabul edilemeyeceğini kabul etmek gerekir. Bu yüzden bonoda düzenleme yerinin belirliliği çerçevesinde bu yerin kısaltılarak yazılması gerekli ve yeterlidir.

Bonoda düzenleme yerinin bir mülki idari birim olması gerekir. $\mathrm{Bu}$ bağlamda mevcut bir yer olması kaydıyla il, ilçe, köy, mahalle bonoda düzenleme yeri olarak tayin edilebilir. Bu yüzden bu yerin semt, cadde, sokak vb. şekilde hukuki belirlilikten uzak bir şekilde kararlaştırılmayacağ1 evleviyetle söylenebilir.

Bonoda düzenleme yerinin yokluğu, noksanlığı veyahut geçersizliği sonucunda sırasıyla soyut borç ikrarı, adi senet, (yazılı) delil başlangıcı araştırması yapılarak bir sonuca varılması gerekir; meğerki açık bono ya da bonodatahrifattan bahsedilsin. Buyüzden bonodaki düzenlemeyerinin olmayış1 
kategorik bir yaklaşım biçimine başvurarak her defasında Yargıtay kararlarına da yansıdığı üzere adi senet şeklindeki kabule tereddütle yaklaşılmasını gerektirir. Hatta soyut borç ikrarı ile adi senedin de farklı kavramlara işaret ettiği de her somut olay açısından göz önünde bulundurulması gereken bir husustur.

\section{KAYNAKÇA}

Alışkan M, "İktisadi Müesseselerde Türkçe Kullanma Zorunluluğu", 2005, VIII(1-2), AÜEHFD, s. 349-377, <https://hukukdergi.ebyu.edu. tr/?p=1305> Erişim Tarihi 25 Kasım 2020.

Bahtiyar M, Kıymetli Evrak Hukuku (Ders Notlar1- Soru Örnekleri), Güncellenmiş 18. Bası, Beta Yayınevi, İstanbul 2020 (Bahtiyar, Kıymetli Evrak).

Bahtiyar M, “Türk Ticaret Kanunu Tasarısı'nın Dili İle Bazı Hükümlerinin Değerlendirilmesi", 2005, 18(61), TBB, s. 47-106, <http://tbbdergisi. barobirlik.org.tr/m2005-61-183> Erişim Tarihi 25 Kasım 2020 (Bahtiyar, TBB).

Bahtiyar M, "805 Sayıl1, "İktisadi Müesseselerde Mecburi Türkçe Kullanılması Hakkında Kanun”un Kapsamı ve Yaptırımı Sorunu”, 2007, II, Prof. Dr. Hüseyin Ülgen'e Armağan, s. 1731-1750 (Bahtiyar, 850).

Bahtiyar M, Anonim Ortaklık Anasözleşmesi, 1. Bası, Beta Yayıncılık 2001. (Bahtiyar, Anasözleşme)

Basler Kommentar Wertpapierrecht, Marc G/ Bruno H/ Gerhard R, 1. Auflage, Helbing Lichtenhahn Verlag 2012.

Baumbach A/ Hefermehl W, Wechselgesetz und Scheckgesetz mit Nebengesetzen und einer Einführung in das Wertpapierrecht, 22. neubearbeitete und erweiterte Auflage, Verlag C.H.Beck München 2000.

Bozer A/ Göle C, Kıymetli Evrak Hukuku, Güncellenmiş ve Genişletilmiş Sekizinci Bası, Banka ve Ticaret Hukuku Araştırma Enstitüsü Yayınları 2018.

Börü L, "Bonoya Dayalı Kambiyo Senetlerine Özgü Haciz Yolu İle Takipte Yetki”, 2016, 65(1), AÜHFD, s. 137-182, <https://dergipark.org.tr/tr/ download/article-file/622108 > Erişim Tarihi 20 Kasım 2020. 
Bülow P, Wechselgesetz/Scheckgesetz, 5. neu bearbeitete Auflage, Verlag C. F. Müller 2013.

Cerrahoğlu M. F, Türk Ticaret Kanununa ve Yargıtay İçtihatlarına Göre Bonoda Mutlak Defiler,1. Bas1, İstanbul İktisadi ve Ticari İlimler Akademisi, Hüsnü Tabiat Matbaası, 1974.

Domaniç H, Kıymetli Evrak Hukuku ve Uygulaması, TTK Şerhi-IV, 1. Bası, Eskin Matbaas1 1990.

Eriş G, Türk Ticaret Kanunu Hükümlerine Göre Kıymetli Evrak, 1. Bask1, Seçkin Yayıncılık 2014.

Gökcan Hasan T, “Özel Belgede Sahtecilik (TCK M.207), 2010, 68(2010/1), Ankara Barosu Dergisi, s. 209-236, <https://dergipark.org.tr/tr/pub/abd/ issue/33777/374082> Erişim Tarihi 20 Kasım 2020.

Gözler K, “6360 Sayılı Kanun Hakkında Eleştiriler (Yirmi Dokuz İlde İl Özel İdareleri ve Köylerin Kaldırılması ve İlçe Belediyelerinin Büyükşehir İlçe Belediyesi Haline Dönüştürülmesi Anayasamıza Uygun Mudur?", 2013, 11(122), Legal Hukuk Dergisi, s. 37-82, <https://www.idare.gen. tr/6360-elestiriler.pdf > Erişim Tarihi 20 Kasım 2020.

Hueck A, Recht der Wertpapiere, 10. Auflage, Verlag Franz Vahlen GmbH Berlin und Frankfurt a. M. 1967.

İmregün O, Kıymetli Evrak Hukuku (Genel Hükümler-Kambiyo SenetleriMakbuz Senedi-Varant), 1. Bas1, Filiz Kitabevi 1995.

İnan N, Türk Hukukunda Hatır Senetleri Ve Özellikle Hatır Bonoları, 1. Bası, Bilgi Basımevi 1969.

Jacobi E, Wechsel-Und Scheckrecht unter Berücksichtigung des ausländischen Rechts, Unveränderter Nachdruck, Walter De Gruyter \& CO. 1956.

Karayalçın Y, Ticaret Hukuku Dersleri (II. Ticari Senetler -Kambiyo Senetleri-, Üçüncü Bask1, Güzel İstanbul Matbaası 1964.

Karlı Ö, Sebebi Gösterilmeyen Borç Tanıması (Mücerret Borç İkrarı) BK. Mad. 17, 1. Bası, Vedat Kitapçı1ık 2008.

Kaşak F E, Sözleşme Özgürlüğünün Sınırı Olarak Kanunun Emredici Hükümlerine Aykırılık, 1. Bası, Onikilevha Yayıncılık 2019.

Kayar İ, Kıymetli Evrak Hukuku, Altıncı Bası, Detay Yayıncılık 2013. 
Kendigelen A, Çek Hukuku, Gözden Geçirilmiş ve Güncelleştirilmiş 5. Bası, Onikilevha Yayıncılık 2019 (Kendigelen, Çek).

Kendigelen A/Kırca İ, Kiymetli Evrak Hukuku (Genel Esaslar-Kambiyo Senetleri), Güncellenmiş 3. Bası, Onikilevha Yayıncılık 2020.

Kınacıoğlu N, Kıymetli Evrak Hukuku, 5. Baskı, Nobel Yayınevi 1999.

Kırca İ, "İktisadi Müesseselerde Mecburi Türkçe Kullanılması Hakkında Kanun Üzerine”, 2007, II, Prof. Dr. Hüseyin Ülgen’e Armağan, s. 19291947.

Kocayusufpaşaoğlu N/ Hatemi H / Serozan R/ Arpacı A, Borçlar Hukuku Genel Bölüm, 5. Basıdan Tıpk1 6. Bask1, Birinci Cilt, Filiz Kitabevi 2014.

Konuralp H, Medeni Usul Hukukunda Yazılı Delil Başlangıcı, Tıpkı Basım, Yetkin Yayınları 2009.

Kuru B, İstinaf Sistemine Göre Yazılmış Medeni Usul Hukuku Ders Kitabı, 1. Bas1, Yetkin Yayınc1lık 2017.

Meier Hayoz A / von der Crone H, Wertpapierrecht, Zweite, überarbeitete Auflage,Stämpfli Verlag AG Bern 2000.

Moroğlu E, "Kambiyo Senetlerinde Düzenleme Yeri”, Makaleler, Onikilevha Yayınc1lik, 2010, s. 507-517.

Muratoğlu T, "Mahalli İdareler Mevzuatında 6360 Sayılı Kanunla Yapılan Değişiklikler", 2015, 20(32), Dicle Üniversitesi Hukuk Fakültesi Dergisi, s. 59-96, <https://dergipark.org.tr/tr/pub/duhfd/issue/23032/246225> Erişim Tarihi 20.11.2020.

Narbay Ş, "Çekte İbraz Sürelerinin Belirlenmesinde Ölçü Alınan "Yer" Kavramına "De Lege Lata" ve "De Lege Ferenda" Çözüm Önerileri", 2003, I, Bilgi Toplumunda Hukuk- Ünal Tekinalp'e Armağan, s. 793821. (Narbay, Armağan)

Narbay Ş, "Türk Ticaret Kanunun Tasarısında Kıymetli Evrak Hukuku Kitabında Yapılan Düzenlemeler Ve Değişiklik Önerilerimiz", 2005, 7(Özel Sayı), DEÜHFD, Prof. Dr. İrfan BAŞTUĞ Anısına Armağan, s. $173-222,<$ http://earsiv.erzincan.edu.tr/xmlui/bitstream/handle/20 $.500 .12432 / 3313 / \%$ c4\%b0RFAN\%20BA\%c5\%9eTU\%c4\%9e \%20 ARMA $\%$ c4\%9eANI.pdf?sequence $=1 \&$ isAllowed $=\mathrm{y}>$, Erişim Tarihi 20 
Kasim 2020.

Özdamar M/ Göktürk K/ Can Mehmet Ç/ Kaşak E, Kıymetli Evrak Hukuku, Birinci Bası, Adalet Yayınevi 2020.

Özdemir H, "Kambiyo Taahhütlerinin Şekil Bakımından Geçerliliğine Uygulanacak Hukuk", 1999, İstanbul Üniversitesi Hukuk Fakültesi Eğitim-Öğretim ve Yardımlaşma Vakfı Yayınları No: 7, Prof. Dr. Nihal Uluocak'a Armağan, s. 261-276.

Öztan F, Kıymetli Evrak Hukuku, Güncelleştirilmiş 21. Bası, Turhan Kitabevi 2017.

Öztan F, Kıymetli Evrak Hukuku, 2. Bask1, Turhan Kitabevi 1997 (Öztan, 1997).

Poroy R/ Tekinalp Ü, Kıymetli Evrak Hukuku Esasları (Çek Kanunun Yorumu İle), Gözden Geçirilmiş 21. Bası, Vedat Kitapçılık 2013.

Pulaşlı H, Kıymetli Evrak Hukukunun Esasları, Genişletilmiş ve Güncellenmiş 5. Bask1, Adalet Yayınevi 2017.

Rehfeldt B / Zöllner W, Wertpapierrecht, 10. Auflage, Verlag C H Beck München 1972.

Reisoğlu S, Çek Hukuku,1. Bası, Yazarın Kendi Yayını 2011.

Schoele W, Der Wechsel, Heft 78, R. Booberg Verlag 1956.

Stanzl G, Wechsel-, Scheck- und sonstiges Wertpapierrecht, I. Band, Hermann Böhlaus Nachf. / Graz-Köln 1957.

Şanlı C / Esen E / Ataman-Figanmeşe İ, 2. Bası, Milletlerarası Özel Hukuk, Vedat Kitapçılık 2014.

Şehirali, Feyzan H, "Yargıtay Kararlarında Karşılıksız Çek”, 1997, 52(14), AÜSBFD, s. 661-691, <https://dergipark.org.tr/tr/pub/ausbf/ issue/3109/43043> Erişim Tarihi 20 Kasım 2020.

Teichmann A, Handelsrecht, 3. Auflage, Nomos UTB 2013.

Tekil F, Kıymetli Evrak Hukuku, 1. Bası, Beta Yayınevi 1980.

Teoman Ö, BONO, Yaşayan Ticaret Hukuku (Hukuki Mütalaalar) KİTAP: 12 2004-2007, 2008, s. 123-128 (Teoman, Hukuki Mütalaalar 149).

Turanlı H, “Türk Hukukunda Alonj”, 2017, 3(1), TFM, s. 119-128, <https:// dergipark.org.tr/tr/pub/tfm/issue/31322/341754> Erişim Tarihi 20 Kasım

208 Ankara Hacı Bayram Veli Üniversitesi Hukuk Fakültesi Dergisi C. XXV, Y. 2021, Sa. 2 
2020.

Uçar S, "6360 Sayılı Büyükşehir Kanun Hükümleri Işığında Çekte "Düzenlenme Yeri” ve "İbraz Süresi” Kavramları Üzerine Bazı Tespit Ve Değerlendirmeler", 2019, 31(140), TBB, s. 331-354, <http://tbbdergisi. barobirlik.org.tr/m2019-140-1824> Erişim Tarihi 20 Kasım 2020.

Uyar T, “İcra Hukukunda Bono'nun (Emre Muharrer Senet'in) Geçerlilik Koşulları”, 2008, 20(74), TBB, s. 290-325, <http://tbbdergisi.barobirlik. org.tr/m2008-74-395> Erişim Tarihi 25 Kasım 2020.

Uyar T/Uyar A/ Uyar C, İcra Hukukunda Kambiyo Senetleri (İ̈. 167-170b), 4. Bask1, Bilge Yayınevi 2013.

Ülgen H / Helvac1 / Kaya / Nomer Ertan F, Kiymetli Evrak Hukuku, Güncellenmiş ve Kısmen Yeniden Yazılmış 11. Bası, Vedat Kitapçılık 2019.

Wiefels J., Recht der Wertpapiere, 41.-43. Tausend Neu bearbeitetete Auflage, 9. Band, 1956. 
